\title{
FRANTIŠEK VAVŘINEC RABAS, OFMCAP (1901-1969) JAKO PEDAGOG A BLÍZKÝ SPOLUPRACOVNÍK LITOMĚŘICKÉHO BISKUPA ŠTĚPÁNA TROCHTY
}

\author{
MARTIN BARUS - MAREK BRČĆK
}

\section{FRANTIŠEK VAVŘINEC RABAS, OFMCAP (1901-1969) AS A TEACHER, AND A CLOSE COLLABORATOR OF ŠTĚPÁN TROCHTA, THE BISHOP OF LITOMĚŘICE}

The article is dedicated to Roman Catholic priest, František Rabas, who was in 1918-1946 member of the Friars Minor Capuchin and thus used his monastic name Vavřinec. The chief aim of the text is to connect his two, so far in effect separately perceived identities, that is, one of the Capuchin historiographer, teacher, and educator, the other of the Rector of the seminary in Litoměřice and a secret vicar general of the Litoměřice bishopric. For this 'subversive' activity, he was in 1954 together with his bishop, Štěpán Trochta, and other collaborators, sentenced to many years in prison. The authors present a comprehensive biography of a notable personage of the Czech Catholic Church and Catholic intellectual circles of the first two thirds of the twentieth century, whose life aptly demonstrates the developments in the Catholic Church.

Keywords: Roman Catholic Church - Catholic clergy - Friars Minor Capuchins - ecclesiastic historians - Catholic seminaries - political prisoners - Church administration

DOI: $10.14712 / 23365730.2021 .20$

František Vavřinec Rabas je polozapomenutá postava našich dějin, která je především známa v souvislosti se svým působením ve vyšších církevních úřadech v litoměřické diecézi na přelomu 40. a 50. let 20. století. V této době užíval Rabas již jen své křestní jméno František. Pod řeholním jménem Vavřinec ho zase znají členové kapucínského řádu a historici českých raně novověkých církevních dějin, jelikož je autorem monografie Řád kapucínský a jeho působení $v$ Čechách v 17. století, ${ }^{1}$ která byla od svého vydání v roce 1938 téměř až do současnosti jedinou a základní prací k dějinám tohoto řeholního společenství v českých zemích pro období baroka. ${ }^{2}$ Často se ale zapomíná na to, že se jedná o tutéž osobu, což je způsobeno tím, že Rabas své křestní a řeholní jméno neužíval nikdy současně, tj. v době

Vavřinec RABAS, Řád kapucinský a jeho působení v Čechách v 17. století, Praha 1938.

2 Marek BrČÁK - Jiří Wolf, Čeští kapucíni v historické perspektivě aneb úvodni slovo editorů, in: tíž (edd.), Pax et Bonum. Kapucíni v Čechách a na Moravě v raném novověku, Praha 2020, s. 11-39, zde s. 16. 
svého působení v kapucínském řádu (1918-1946) striktně používal pouze řeholní jméno Vavřinec $^{3}$ a po vystoupení z něj se vrátil ke křestnímu jménu František (1946-1969). ${ }^{4}$

František ${ }^{5}$ Rabas, který se narodil dne 20. 9. 1901 v Žatci, pocházel z česko-německé rodiny. Jeho otec Josef Rabas ${ }^{6}$ (nar. 10. 6. 1876 v Kralovicích), jenž byl povoláním švec, se po svatbě (15. 1. 1900) s Rosou Motykovou ${ }^{7}$ (nar. 26. 3. 1875 ve Vršovicích, ${ }^{8}$ okr. Karlín), usadil v Žatci, kde vedl malou ševcovskou dílnu (nejprve při domu č. p. 466, následně č. p. 816), kterou po jeho předčasné smrti (zemřel 17. 9. 1915 v Žatci) ${ }^{9}$ vedla jeho žena. ${ }^{10}$ Františkův bratr Josef Rabas (1908-2003) se stal diecézním knězem v litoměřické diecézi, kde mj. působil jako sekretáŕ biskupa Antona Aloise Webera (1877-1948). ${ }^{11}$ Druhým sourozencem byla sestra Anna Rabasová, která v dospělosti pracovala jako hospodyně v domácnostech. Celkové rodinné poměry charakterizoval v dopise (24. 3. 1918, Žatec), který doporučoval F. Rabase (tehdy veden jako kandidát vstupu - viz dále) přijmout za člena kapucínského řádu a který byl adresován provinčnímu ministrovi česko-moravské provincie Řehoři Kottovi (1863-1926), ${ }^{12}$ tehdejší kvardián žateckého kapucínského konventu

3 V souladu s řádovou historickou tradicí respektující ideály kapucínské skromnosti se dokonce často podepisoval jen jako Laurentius Ziattecensis, tudíž nepoužíval své př́ijmení (pod touto variantou ho lze najít v katalozích česko-moravské provincie). K této praxi blíže viz Marek BRčÁK, Působeni kapucínského řádu v Čechách a na Moravě 1599-1783 (v tisku).

4 Jako dvě samostatné osobnosti je uvádí i přední znalec dějin české teologie 20. století Vojtěch NovotNÝ, Katolická teologická fakulta 1939-1990. Prolegomena k dějinám české katolické teologie druhé poloviny 20. století, Praha 2007, s. 46, 53, 102, 108, 119, 520.

5 Jeho druhé křestní jméno, které ale neužíval, bylo Josef.

6 Jeho rodiče byli Josef Rabas (tkadlec) a Anna (roz. Šifner, krejčová), kteří pocházeli rovněž z Kralovic.

7 Jejími rodiči byli Paul Motyka, který pracoval jako námezdní dělník a narodil se v Těšíně, a Marie (roz. Mašek), jež byla dcerou správce velkostatku v Oseku (okres Strakonice), odkud i pocházela.

8 Vršovice byly povýšeny na městečko v roce 1875, na město pak v roce 1902 a od roku 1922 jsou pražskou městskou částí. Václav LedvinKA - Jiří PEŠEK, Praha, Praha 2000, s. 525-535, 543, 565.

9 Státní oblastní archiv (dále jen SOA) Litoměřice, Sbírka matrik Severočeského kraje, inv. č. 10450, sign. 189/92, Matrika zemřelých farnosti Žatec (1913-1919), s. 140.

10 Tamtéž, inv. č. 10439, sign. 189/84, Matrika narozených farnosti Žatec (1901-1903), s. 98.

11 Josef Rabas byl po druhé světové válce jako kněz německé národnosti odsunut $\mathrm{z}$ Československa. V kněžské službě pokračoval ve Spolkové republice Německo, kde působil jako teolog na univerzitě ve Würzburgu. Kromě toho se aktivně angažoval za usmíření mezi Čechy a Němci, mj. v rámci občanského sdružení Ackermann-Gemeinde, jehož pracovní centrum v Ř́mě vedl v letech 1976 až 1991. V roce 1998 se stal čestným kanovníkem litoměřické katedrální kapituly. Hojně publikoval o stavu katolické církve v Československu, známost si však získal vydáním životopisu biskupa Webera, který vyšel také v češtině (Josef RABAs, Biskup Anton Alois Weber, Kostelní Vydří - Litoměřice 2013). SOA Litoměřice, Sbírka matrik Severočeského kraje, inv. č. 11048, sign. 189/90, Matrika narozených farnosti Žatec (1908-1910), s. 88; Oto Mádr, Josef Rabas, Teologické texty 14, 2003, s. 162; Martin BARus, Stručný životopis Josefa Rabase, in: J. Rabas, Biskup Anton Alois Weber, s.166-167; Michal SkLENÁř, ,Dávám se cele k disposici k pastoraci v pohraničí. “ Snahy o poválečnou obnovu a personální situace litoměřcké diecéze po druhé světové válce, Securitas imperii 32/1, 2018, s. 130-159, zde s. 137. Do archivu Biskupství litoměřického (dále jen ABL) byla po Rabasově úmrtí předána jeho cenná osobní pozůstalost. Dosud se jedná o nezpracovaný a neprŕliš přehledný fond, jehož význam pro poválečné česko-německé vztahy především v církevní oblasti je nezanedbatelný.

12 Řehoř Kott, křestním jménem František, narozen 1. 10. 1863 v Červeném Zahoří, obláčka 21. 9. 1882, věčné sliby 6. 1. 1887, je v česko-moravské provincii doložen jako kvardián v Opočně (1893-1900), superior v Praze na Novém Městě (1900-1916, 1920-1926), provinční definitor (1905-1916, 1919-1922) a ministr (1916-1919). Od roku 1919 zastával též úřad konzistorního rady v hradecké diecézi. Zemřel 26. 4. 1926 v Praze na Novém Městě. Pacifik MatĚJKa, Seznamy představených kapucínských klášterů podř́zených provincialátu v Praze (1599-2005), Paginae historiae 13, 2005, s. 140-267, zde s. 192; TÝž, Seznam provinciálů, definitorů a ostatních predstavených správních jednotek kapucínského Řádu s historickým sídlem v Praze (a Vidni), Paginae historiae 14, 2006, s. 259-343, zde s. 317-319. 
Kamil Florián Pospíšil (1871-1941) ${ }^{13}$ následovně: „Je to hodný chlapec [F. Rabas], který je nezkažený věrící, syn chudších rodičù (...)“.14

Před vstupem do kapucínského řádu F. Rabas studoval nejprve na biskupském gymnáziu v Bohosudově (I.-IV. třída, 1912/1913-1915/1916) a následně na klasickém gymnáziu v Žatci (V.-VIII. třída, 1916/1917-1919/1920), přičemž poslední dva ročníky dokončil až po přijetí do řádu. Středoškolské studium zakončil složením maturitní zkoušky v červnu $1920 .{ }^{15} \mathrm{Na}$ základě dochovaných vysvědčení, která se nacházejí v jeho osobní složce uložené v provinčním archivu česko-moravské kapucínské provincie, lze konstatovat, že F. Rabas byl „průměrným“ studentem. V rámci čtyřstupňové klasifikace byl vždy hodnocen z jednotlivých předmětů bud" ,gut" (2) anebo ,,genügend“" (3). ${ }^{16}$

F. Rabas byl v kontaktu s kapucíny od svého útlého dětství, jelikož v jeho mateřském městě už od roku 1675 fungovala jejich řeholní komunita. ${ }^{17}$ Intenzivní vztahy s řádem mimo jiné potvrzuje i již citovaný dopis kvardiána Pospíšila, v němž se přimlouvá za Rabasovo přijetí do noviciátu. ${ }^{18}$ Nicméně dle dokumentů nacházejících se v osobní složce F. Rabase přijetí neproběhlo zcela automaticky, uchazeč o vstup do řádu totiž musel v souladu s tehdy platnými řádovými konstitucemi z roku $1909^{19}$ a Kodexem církevního práva z roku $1917^{20}$ splnit několik základních podmínek.

13 Kamil Pospíšil, křestním jménem Florián, narozen 21. 7. 1871 v Pravčicích, obláčka 21. 7. 1887, věčné sliby 15. 11. 1892, v česko-moravské provincii působil jako dlouholetý kvardián v Žatci (1902-1939), provinční definitor (1916-1919, 1922-1929) a ministr (1919-1922). Zemřel 6. 5. 1941 v Žatci. P. MaTĚJKA, Seznamy představených, s. 195; TÝŽ, Seznam provinciálio, s. 318-320.

14 Národní archiv Praha (dále jen NA Praha), Kapucíni - provincialát a konventy, Praha (dále jen ŘK), Spisy, inv. č. 31, kart. č. 176, Osobní složka Vavřinec Rabas (nepaginováno).

15 Rabasovým třídním učitelem v době studia na žateckém gymnáziu byl Josef Schiepek (1860-1943), který ho vyučoval němčině, řečtině, dějepisu a filozofické propedeutice a který je mj. autorem několika článků o německých nářečích v oblasti Poohří. Jiří MATYÁš (ed.), Dějiny žateckého gymnázia: Schola Zatecensis, Žatec 2009, s. $85,87$.

16 Viz opisy Rabasových vysvědčení nacházející se v jeho osobní složce, které si vedení provincie vyžádalo od ředitelů gymnázií před jeho vstupem do řádu. NA Praha, ŘK, Spisy, inv. č. 31, kart. č. 176, Osobní složka Vavřinec Rabas (nepaginováno).

17 Kapucíni přišli do Žatce v roce 1675 na základě pozvání místní městské rady (NA Praha, ŘK, Spisy, inv. č. 622, kart. č. 457, sign. A4-A5). Klášter s kostelem Nanebevzetí Panny Marie (jeho vysvěcení proběhlo dne 10. 10. 1683 - tamtéž, sign. 19), byl budován jednak z menší části odkazů žateckých měšt'anů (tamtéž, sign. A9-A15) a především pak za finančního přispění Ludmily Evy Františky Krakovské z Kolovrat (1616-1695) (tamtéž, sign. A16) a Marie Sidonie z Varrensbachu (†1691). Během první světové války, tj. v době těsně před Rabasovým vstupem, konvent sloužil jako vojenský lazaret. Klášter byl zrušen v roce 1950 v rámci tzv. Akce K, od té doby je v majetku města. Nejdříve sloužil až do 80. let jako domov důchodců, nyní probíhá jeho rekonstrukce S úmyslem vybudovat zde polyfunkční robotické a spolkové centrum. Srov. Pavel VLČEK - Petr SOMMER - Dušan Foltýn, Encyklopedie českých klášterů, Praha 1997, s. 703.

18 Blízký vztah celé rodiny ke kapucínům, resp. k řádovému kostelu v Žatci potvrzuje i prrípisek na předsádce modlitební knihy Josefa Rabase „Eigenthum des Josef Rabas Saaz Ministrand in Kloster “; Knihovna Biskupství litoměřického, Der heilige Kreuzweg unseres Herrn Jesu Christi, wie er vermöge bischöflicher Genehmigung an den Sonntagen während der heiligen Fastenzeit in der Kirche der P. P. Kapuziner geführt wird, Saaz 1908 (bez signatury).

19 [Fidel Elizondo (ed.)], Constitutiones Ordinis Fratrum Minorum Capuccinorum saeculorum decursu promulgatae, tom. II, Constitutiones recentiores (1909-1925), Romae 1986, s. 209.

20 Codex Iuris Canonici Pii X Pontificis Maximi, Romae 1917. Jeho český překlad: František Kop (ed.), Překlad Kodexu kanonického práva, Olomouc 1969 (strojopis, pracovní text komise při Cyrilometodějské bohoslovecké fakultě v Praze se sídlem v Litoměřicích, pobočce Olomouc). Pravidla pro přijetí do noviciátu specifikují kánony č. 538-552 (tamtéž, s. 150-154). 
F. Rabas nejprve podal písemnou žádost o vstup do kapucínského řádu, která byla adresována provinčnímu ministru Ř. Kottovi (17. 3. 1918, Žatec), ${ }^{21}$ o přijetí tedy žádal v 16 letech, což byla tehdy minimální hranice pro vstup do řádu. Následně však musel doložit svůj zdravotní stav, ${ }^{22}$ tak jako dnes, ale už i v raném novověku ${ }^{23}$ mohl být ke kapucínům přijat jen dostatečně fyzicky a duševně zdatný uchazeč. Kromě toho F. Rabas musel prokázat i svoji trestní bezúhonnost. ${ }^{24}$ Samozřejmostí bylo i potvrzení, že je svobodný a pokřtěný muž, který je manželského původu a jenž má vlohy (zbožnost, mravy, vědomosti atd.) pro řeholní povolání. ${ }^{25}$

Vzhledem k okolnosti, že F. Rabas byl v době svého vstupu ke kapucínům poloviční sirotek a zároveň tehdy nedosáhl ještě plnoletosti, musel jeho touhu stát se řeholníkem schválit mj. i opatrovnický soud ${ }^{26}$ a také jeho zákonný zástupce, kterým byla jeho matka Rosa. ${ }^{27}$ Vedení provincie se dále zajímalo o studijní vlohy kandidáta, mj. proto se v osobní Rabasově složce v provinčním archivu dochovala jeho gymnaziální vysvědčení. Sledovány však byly i další předpoklady, například hudební nadání. To F. Rabas dokládal vysvědčením z městské hudební školy v Žatci, mj. aktivně hrál na violu a pozoun a byl i členem zdejšího sboru fungujícího při této instituci. ${ }^{28}$

Přihlíženo bylo i k jazykovým dovednostem, v Rabasově př́ípadě byla oceňována jeho znalost jak německého, tak i českého jazyka (mj. po dobu gymnaziálních studií volitelně studoval i český jazyk). ${ }^{29} \mathrm{~V}$ této souvislosti kvardián K. Pospíšil v již uváděném dopise provinčnímu ministrovi Ř. Kottovi sděluje: ,[Rabas] umí česky i německy, je vlastně Čechem, tedy nebude nikdy dělati nadutého Němce. "30 Z úryvku je patrné, že jako negativní okolnost bylo vnímáno př́ípadné silné nacionální cítění, které vzhledem k tehdy smíšenému charakteru česko-moravské provincie nebylo z pochopitelných důvodů žádoucí. ${ }^{31} \mathrm{~V}$ neposlední řadě byl brán ohled i na povahové vlastnosti a na řečnické dovednosti kandidáta, které v př́ípadě F. Rabase nebyly bez vady, jelikož trochu koktal, obzvláště v rozčilení. K. Pospíšil doslovně píše: „Háček přitom je, že [Rabas] při rozčllení, když má najednou mluviti, trošku koktá, ale dle mého zdání a mé dlouholeté praxe, není chyba taková, aby byla na závadu.

21 NA Praha, ŘK, Spisy, inv. č. 31, kart. č. 176, Osobní složka Vavřinec Rabas (nepaginováno).

22 Rabasovu zdravotní způsobilost ke vstupu do řádu potvrdil Dr. [Vilém] Bergmann (13. 8. 1918, Žatec). NA Praha, ŘK, Spisy, inv. č. 31, kart. č. 176, Osobní složka Vavřinec Rabas (nepaginováno).

23 Toto kritérium bylo velice zdůrazňováno v řádových konstitucích i v období raného novověku (Pavel PRIHATNÝ (ed.), Konštitúcie sv. Eufémie (Rím, 1536), Studia Capuccinorum Boziniensia 2, 2014, s. 13-67, zde s. 17-18; V. RABAS, Řád kapucínský, s. 64) a je shodné pro více řeholních řádů.

24 To potvrdil městský úřad v Žatci (8. 8. 1918). NA Praha, ̌̌K, Spisy, inv. č. 32, kart. č. 176, Osobní složka Vavřinec Rabas (nepaginováno).

25 Osvědčovací listy o řádném původu řeholního kandidáta vydal jednak ordinář litoměřické diecéze Josef Gross (1866-1931) (10. 7. 1918, Litoměřice) a jednak žatecký farní vikáŕ Siard Kůrka, OPraem (*1887) (7. 8. 1918, Žatec). Tamtéž (nepaginováno).

26 Povolení na základě šetření místodržitelství vydal okresní soud v Žatci (12. 10. 1918, Žatec). Tamtéž (nepaginováno). Česko-moravská kapucínská provincie se v této souvislosti mj. stala i př́iemcem Rabasova sirotčího důchodu v roční výši 438 Kčs 66 haléřů, který mu byl vyplácen do dosažení 18. let, tj. do září 1919, tamtéž (nepaginováno).

27 Svolení je datováno 12. 8. 1918 v Žatci, tamtéž (nepaginováno).

28 Vysvědčení bylo vydáno 13. 7. 1918, tamtéž (nepaginováno).

29 Viz jeho vysvědčení v osobní složce, tamtéž (nepaginováno).

30 Dopis K. Pospíśila adresovaný Ř. Kottovi (24. 3. 1918), tamtéž (nepaginováno).

31 Ostatně F. Rabas se hlásil celý život k české národnosti (viz například dokumenty týkající se jeho vojenské služby či policejní odhlášky dochované v jeho osobní složce), tamtéž (nepaginováno). Není bez zajímavosti, že jeho rodný bratr Josef se hlásil k německé národnosti, mj. proto byl z Československa roku 1946 odsunut. 
Vzdor tomu, že je zbožný, maji ho jeho kollegové i profesoři rádi. Známkou jeho dobroty je, že protestanský profesor (odpadek) má na něj pivku, ovšem nezávaznou.“32

$\mathrm{Z}$ výše uvedeného je zřejmé, přestože česko-moravská provincie v době Rabasova vstupu do řádu prožívala hlubokou personální krizi, ${ }^{33}$ kterou dokázala překonat až v době první československé republiky (viz dále), tak si provinční ministři v souladu s řádovými předpisy novice pečlivě vybírali. V roce 1914 čítala česko-moravská provincie 116 členů (z toho 29 členů bylo na frontě, z nichž 11 zde zemřelo) a 21 klášterů, jednu řeholní komunitu tak v průměru tvořili pouze čtyři řeholníci. 34

Po předložení všech výše uvedených dokumentů nakonec $\check{R}$. Kott schválil vstup F. Rabase do kapucínského řádu. Obláčka, tj. slavnostní přijetí do řádu, při níž přijal řeholní jméno Vavřinec, se konala dne 25. 8. 1918 v konventním kostele Narození Páně v Opočně, při jehož klášteře tehdy fungoval noviciátní dům česko-moravské provincie. ${ }^{35}$ Nicméně dotyčný zde neabsolvoval kompletní roční noviciát (viz dále), a to vzhledem $\mathrm{k}$ tomu, že v letech 1918-1920 dokončoval středoškolské studium na žateckém gymnáziu, i když je možné, že sedmý ročník mohl zčásti studovat i dálkově. Nicméně dle profesního lístku, který se váže k jeho prvním časným slibům, které složil na Slavnost Zvěstování Páně 25. 3. 1920 v klášterním kostele Korunování Panny Marie v Žatci, ${ }^{36}$ prokazatelně pobýval při žateckém konventu od záŕí 1919 do června 1920, při němž byl veden už jako „clericus, philosophiae studens“". To potvrzuje i výroční katalog česko-moravské provincie z roku $1920 .{ }^{37}$

Vzhledem $\mathrm{k}$ tehdy panující personální krizi v česko-moravské provincii neprobíhala řádová formace v ní dle řádových konstitucí úplně „standardním“ způsobem, např́íklad v provincii chybělo řádové filozofické a teologické studium. Kandidáti kněžství tak po maturitě navštěvovali běžný diecézní seminář, např́klad v Praze, Brně či Olomouci, kde studium filozofie a teologie nebylo odděleno a hovořilo se prostě o studiu teologie. ${ }^{38}$ To byl i Rabasův př́pad. Nejprve byl studentem teologie ${ }^{39}$ na Cyrilometodějské bohoslo-

32 Dopis K. Pospíšila adresovaný Ř. Kottovi (24. 3. 1918), tamtéž (nepaginováno).

33 Během 19. století v důsledku sekularizačních vlivů došlo k výraznému zmenšení počtu kapucínů působících v česko-moravské provincii, a to zejména oproti zlatému věku řádu v 18. století. Nejvíce členů česko-moravská provincie čítala v roce 1753 , konkrétně 824 , kteří působili při 36 klášterech, při jedné komunitě tedy v průměru působilo na 23 řeholníků. M. BRČÁK, Působení kapucínského řádu (v tisku). Pro srovnání při dnešní Provincii kapucínů v České republice působí 36 členů žijících při pěti klášterech. <https://kapucini.cz/domains/kapucini. cz/index.php/o-nas> [cit. 6. 7. 2021].

34 Milan BubEN, Encyklopedie řádi a kongregacív českých zemích, III/1, Praha 2006, s. 388; Pacifik MATĚJKA, Ne mečem a měšcem, ale bezbranností lásky, Velehrad 1999, s. 33-34.

35 Fungování noviciátu při klášteru v Opočně v této době mj. dokazuje dochovaná kniha slibů Liber professionum in Ordine Patrum Capucinorum Opočnae z let 1897-1946. NA Praha, Kapucíni Opočno, inv. č. 11, kart. č. 6.

36 Viz profesní lístek vážící se k prvním časným slibům (25. 3. 1920, Žatec), jenž je podepsán i členy zdejší komunity, uložený v osobní složce V. Rabase. NA Praha, ̌̌K, Spisy, inv. č. 31, kart. č. 176, Osobní složka Vavřinec Rabas (nepaginováno).

37 Tamtéž, inv. č. 30, kart. č. 138, Catalogus provinciae Bohemo-Moraviae Ordinis Minorum Sancti Patris Francisci Capucinorum Anno 1920 (nepaginováno).

38 Srov. P. MATĚJKA, Ne mečem a měšcem, s. 34.

$39 \mathrm{~K}$ tehdejšímu římskokatolickému teologickému studiu v Československu na základě normativních předpisů podrobněji Otto Placht - František HaVElka, Předpisy pro vysoké školy republiky československé, Praha 1932, s. 1284-1289. 
vecké fakultě v Olomouci (1920/1921-1921/1922), ${ }^{40}$ následně na švýcarské ${ }^{41}$ Freiburské univerzitě $(1922 / 1923),{ }^{42}$ Univerzitě Karlově v Praze $(1923 / 1924)^{43}$ a opět v Olomouci (1924/1925). ${ }^{44}$ Studium na teologických fakultách V. Rabas zakončil pouze vysvěcením na kněze, nikoliv ziskem doktorátu (ten si dodělal až po druhé světové válce, viz dále). Rabasovo kněžské svěcení proběhlo dne 15. 3. 1925 v kapli Narození Páně při arcibiskupské rezidenci v Olomouci a světitelem byl arcibiskup Leopold Prečan (1866-1947). ${ }^{45}$ V rámci dokončení řádové formace složil v této době i věčné sliby, konkrétně se tak stalo dne 10. 1. 1925 v olomouckém konventním kostele Zvěstování Páně. ${ }^{46}$

40 Doloženo na základě Rabasovy žádosti k udělení svěcení první tonzury (prima tonsura) od olomouckého arcibiskupa (20. 4. 1921, Olomouc). Žádosti však nemohlo být ihned vyhověno, jelikož konzistoř poukázala na nesrovnalosti ohledně kanonické platnosti vstupu do noviciátu a složení časných slibů. Rozporována byla skutečnost, že noviciát neproběhl v noviciátním domě, tak jak požadoval tehdy platný Kodex církevního práva (Kán. 572, 555). F. Kop (ed.), Překlad Kodexu kanonického práva, s. 154, 157. Z tohoto důvodu se V. Rabas a tehdejší provinční vikář a definitor Norbert Smékal (1874-1934) obrátili na římské ústředí řádu. Generální ministr Giuseppe Antonio Bussolari (1869-1939) a prokurátor Melchior Pineda Capo (1871-1936) platnost vstupu do řádu a časných slibů se souhlasem (3. 4. 1922, Ř́m) kardinála prefekta Kongregace pro biskupy a řeholníky Theodora Valfrèho di Bonza (1853-1922) potvrdili. Kardinál T. Valfré di Bonza zároveň povolil udělení první tonzury. K svěcení došlo dne 20. 9. 1922 v seminární kapli sv. Alexia a vykonal jej olomoucký arcibiskup Antonín Cyril Stojan (1851-1923). NA Praha, ŘK, Spisy, inv. č. 31, kart. č. 176, Osobní složka Vavřinec Rabas (nepaginováno); Zemský archiv Opava (dále jen ZA Opava), pob. Olomouc, Arcibiskupská konzistoř Olomouc, Knihy, inv. č. 19, Matrika biskupských úkonů (1906-1950, nepaginováno). Za upozornění na pramen děkujeme kolegyni PhDr. Stanislavě Kovářové.

41 K Rabasově odeslání na studia do Švýcarska došlo s nástupem italského generálního komisaře Pacifika Nanniho do čela česko-moravské provincie (viz dále), který ji vedl de facto v „nucené správě“. K tomuto kroku bylo přikročeno po generální vizitaci provincie, kterou uskutečnil ve dnech 23. 1. 1922 - 15. 2. 1922 Eligius Jensen (1873-1936) z rýnsko-westfálské provincie. Vizitace pro česko-moravskou provincii dopadla velmi nepř́iznivě, a to zejména kvůli stavu zdejší řádové formace. P. MATĚJKA, Seznamy provinciálů, s. 319; TÝž, Ne mečem a měšcem, s. 34-35.

42 Doloženo na základě materiálů týkajících se vojenské služby Vavřince Rabase, který byl odveden v roce 1921. NA Praha, ŘK, Spisy, inv. č. 31, kart. č. 176, Osobní složka Vavřinec Rabas (nepaginováno). Vojenskou službu nakonec Rabas vykonal (na základě udělené výjimky) při studiích na Univerzitě Karlově v Praze jako pomocný zdravotník při divizní vojenské nemocnici v pražských Střešovicích (1923-1924). Archiv Univerzity Karlovy (dále AUK), Katolická teologická fakulta Univerzity Karlovy, Katalogy posluchačů ZS 1923/1924 a LS 1924. Tím však pro V. Rabase vojenské povinnosti neskončily, ve 20. a 30. letech se zúčastňoval jako zdravotník a duchovní povinných cvičení a k 1. 1.1933 byl dokonce povýšen do hodnosti nadporučíka v záloze. Archiv bezpečnostních složek (dále jen ABS), sbírka Správa vyšetřování STB - vyšetřovací spisy (V), arch. č. V-2309 MV, složka V_2309_MV_obalka_02, scan 0087-0088. Za pomoc s dohledáním pramenů v ABS děkujeme kolegovi Mgr. Markovi Sukovi.

43 Během studia na Karlově univerzitě navštěvoval přednášky z těchto předmětů: Všeobecná mravověda, Zvláštní mravověda, O ctnostech rozumově mravovědných a občanských (Josef Kachník, 1859-1940), Otázky vybrané apologetické (Alois Kudrnovský, 1875-1956), Náboženství v Egyptě (Josef Hanuš, 1876-1928), Křest’anská asketika, Křest’anská mystika (Josef Čihák, 1880-1960), Dějiny náboženství v Čechách (František Xaver Stejskal, 1866-1924); a seminářŭ: filozofický (Cyril Jež, 1876-1930) a apologetický (Alois Kudrnovský). AUK, Katolická teologická fakulta Univerzity Karlovy, Katalogy posluchačů ZS 1923/1924 a LS 1924. Bohužel nelze zjistit, jaký vliv měli tito vyučující na Rabasovo další směřování.

44 ZA Opava, pob. Olomouc, Univerzita Palackého Olomouc, Knihy, inv. č. 956, Podací protokol teologické fakulty 1915/1916-1927/28, s. 462, č. j. 64 (1924/1925), Vydáno vysvědčení o zkoušce z mravovědy, kterou V. Rabas absolvoval 26. 10. 1924.

45 Podjáhenské svěcení obdržel 7. 3. 1925 v seminární kapli sv. Alexia v Olomouci. Zde mu bylo následně o den později uděleno i jáhenské svěcení. Konsekrátor byl vždy arcibiskup L. Prečan. ZA Opava, pob. Olomouc, Arcibiskupská konzistoř Olomouc, Knihy, inv. č. 19, Matrika biskupských úkonů (1906-1950, nepaginováno).

46 Viz profesní lístek vážící se k věčným slibům (10. 1. 1925, Olomouc), jenž je podepsán i členy zdejší komunity, uložený v osobní složce V. Rabase. NA Praha, ŘK, Spisy, inv. č. 31, kart. č. 176, Osobní složka Vavřinec Rabas (nepaginováno). 
Po dokončení formace, vzhledem $\mathrm{k}$ jeho dalšímu pedagogickému směřování (viz dále), absolvoval desetiměsíční zahraniční studijní stáž (od 9/1925 do 6/1926) na tzv. serafínských školách zřizovaných kapucínským řádem v Německu, Francii, Belgii a Nizozemí. ${ }^{47}$ Po návratu do Československa je V. Rabas od 1. 9.1926 doložen jako prefekt, tj. představený, a preceptor na serafínské škole při hradčanském konventu. ${ }^{48} \mathrm{~V}$ důsledku sekularizace, ${ }^{49}$ probíhající v 19. století, se nejen v českých zemích, ale i v celé Evropě snížil počet všech řeholníků a řeholnic u „tradičních“ řádů..$^{50}$ Nedostatek noviců postihl i kapucíny. Tento fakt, navíc podpořen vysokým počtem chudé křest’anské mládeže, která neměla prostředky na vyšší vzdělání, ${ }^{51}$ přivedl kapucíny v době generalátu Bernarda Christena (1837-1908) ${ }^{52}$ na myšlenku založení pedagogických zařízení pro dospívající mládež a tím i vytvoření základny pro získávání dorostu. Tyto instituce se nazývaly serafínské školy. ${ }^{53}$ Název je

47 ABS, sbírka Správa vyšetřování STB - vyšetřovací spisy (V), arch. č. V-2309 MV, složka V_2309_MV_ mapa_02, scan 0098.

48 Tamtéž; Knihovna Provincie kapucínů v České republice, pob. Praha (dále jen KPK Praha), sign. PK 00467, Catalogus Ordinis Minorum S. P. Francisci Capucinorum Almae Provinciae Bohemo-Moravae pro Anno Domini 1927, s. 5.

$49 \mathrm{~K}$ tomuto procesu, který je poměrně různě definován, viz např́ílad Lukáš FASORA - Jiř́i HANUŠ - Jiří MALí̌ (edd.), Sekularizace českých zemí v letech 1848-1914, Brno 2007. Na druhou stranu je potřeba podotknout, že pokles významu „tradičních“ řeholních řádů v průběhu 19. století nemusel být zaprííciněn pouze sekularizací, lze jej vysvětlit i neschopností se přizpůsobit nové situaci na „náboženském trhu“ (Peter Ludwig Berger) či „trhu se spásou duše“ (Tomáš Malý). Peter Ludwig Berger, A market Model for Analysis of Ecumenicity, Social Research 1, 1963, s. 77-93; Tomáš MaLÝ, Smrt a spása mezi Tridentinem a sekularizací. Brněnští měštané a proměny laické zbožnosti v 17. a 18. století, Brno 2009, s. 198-236.

50 Naopak v 19. století nastal velký rozvoj řeholních kongregací, kterým dosud česká historiografie nevěnovala př́liš pozornosti, výjimku představuje například zdařilá dvoudílná monografie: Dana JAKšIč̌ovÁ, Dcery své doby? Školské sestry v českých zemích v letech 1851-1938 (1950), I-II, České Budějovice 2012 (=Jihočeský sborník historický 81, 2012 - supplementum 5).

51 K této problematice u nás nejnověji Martin JeMELKA - Jakub ŠToFANí, Vira a nevíra ve stínu továrních komínů. Náboženský život průmyslového dělnictva v českých zemích (1918-1938), Praha 2020.

52 Bernard Christen, křestním jménem Edouard, narozen 24. 7. 1837 v Andermatu, obláčka 1855, byl členem švýcarské provincie, při níž působil jako lektor teologie, novicmistr a provinční ministr (1879-1882). Úřad generálního ministra zastával v letech 1884-1908. Zemřel 30. 3. 1909 v Ingebohl. Lexicon Capuccinum. Promptuarium historico-bibliographicum Ordinis Fratrum Minorum Capuccinorum (1525-1950), Romae 1951, s. 400.

53 Ve stanovách hradčanské serafínské školy z roku 1926 se doslovně píše: „Serafínská škola v Praze jest zř́izena za tím účelem, aby vychovávala zbožné a nadané hochy, kteří by v řádě sv. Františka jako budoucí kněží řádu Kapucínů slovem i životem hlásali v československé republice blahodárné učení sv. Evangelia a pracovali na mravní obnově československé[ho] národa. Tedy Serafínská škola není ani konviktem pro študenty, ani výchovným ústavem pro kněšský dorost světský, nýbrž je to výchovný ústav pro ty, kteří se chtějí stát kněžími řádu kapucínského.“ Účelu vzniku serafínské školy odpovídaly i podmínky přijetí: „,1. Náklonost ke stavu řeholnímu; 2. Mravní způsobilost, tj. nelíčená zbožnost, upř́mnost, nevinnost srdce a poslušnost; 3 . Aspoň prostřední nadání; 4. Vysvědčení, že s dobrým prospěchem prošel obecnou školu nebo některou tr̂́ídu měšt’anské školy; 5. Pevné zdraví [...] K žádosti bud' též přiloženy: 1 . Kř̌estní list; 2. Poslední školní vysvědčení; 3. Lékařské vysvědčení; 4. Vysvědčení mravů vystavené od duchovní správy; 5. Prohlášení rodičủ, že se všemi podmínkami od ústavu žádanými souhlasí.“NA Praha, ŘK, Spisy, inv. č. 376, kart. č. 368. V obdobném duchu hovoří i stanovy třebíčské serafínské školy: „Serafínská škola jest ústavem, kde se nadaní a zbožní hoši vychovávají výhradně jen pro řád kapucínský; není tedy ani konviktem pro studenty, ani výchovným ústavem pro kněžský dorost světský, nýbrž je to výchovný ústav pro ty studenty, kteří se chtějí státi kněžími řádu kapucínského. Kdo tedy dospěl k poznání, že není povolán k životu řeholnímu v řádě kapucínském, nebo kdo předvídá, že rodiče mu odepřou dovolení ke vstupu do řádu, jest ve svědomí zavázán ihned opustiti ústav. Kdo tak nečiní, jest vetř̌elcem, okrádá řád a zneuživá peněz poskytnutých od dobrodinců ř́du pro výchovu dorostu řádu.“ Moravský zemský archiv (dále jen MZA) Brno, E 37 Kapucíni Třebíč, inv. č. 74. Jejich edice uvedena in: Vojtěch MaLach, Dějiny kapucinského kláštera v Třebiči, Diplomová práce, Katolická teologická fakulta Univerzity Karlovy, Praha 2009, s. 103-115, citace je na s. 103. 
odvozen z přídomku zakladatele řádu sv. Františka z Assisi neboli sv. Františka Serafínského. Měsíční školné na těchto ústavech u nás v době první československé republiky činilo 60 Kčs (od roku 1937 bylo ve výši 100 Kčs) na chovance, ${ }^{54}$ za to kapucínský řád podporoval svoje studenty po všech stránkách. Poskytoval jim stravu, ubytování, praní prádla a učebnice. ${ }^{55}$ Skutečné náklady však několikanásobně převyšovaly př́ijmy získané ze školného, kapucíni tedy za pomoci dobrodinců ${ }^{56}$ celý projekt z velké části dotovali, ${ }^{57}$ jak mj. dokládají dochované účty ze serafínských škol fungujících při hradčanském ${ }^{58}$ a třebíčském konventu (viz dále). ${ }^{59}$

První serafínská škola v českých zemích byla otevřena roku 1896 v Olomouci. ${ }^{60}$ Další vznikly v Mostě (1922), ${ }^{61}$ v Praze na Hradčanech (1926) ${ }^{62}$ a Třebíči (1934) ${ }^{63}$ - ta nahradila olomouckou serafínskou školu přestavěnou na řádové teologické studium (viz dále). V roce 1932 byly k česko-moravské provincii připojeny slovenské kláštery v Pezinku a Bratislavě, při němž od roku 1928 též fungovala serafínská škola. ${ }^{64}$ Serafínské školy, na nichž

54 Kromě toho chovanci měli povinnost na počátku školního roku si s sebou do ústavu přinést: 1. Prádlo: 6 košil, 6 spodků, 6 kapesníků, 6 párů ponožek, 4 ručníky, několik límců a kravat; 2. Obuv: 2 páry bot a jeden pár střevíců pro dủm (papuče); 3. Ložní prádlo: 2 ložní plátna, a sice tyto rozměry: délku $220 \mathrm{~cm}$, šířka $130 \mathrm{~cm}$. $\mathrm{K}$ tomu potřebné polštáře a peřinu; 4. Slušný oblek, a sice jeden pro všední den a jeden pro svátek; 5 . slušný klobouk a čepici; 6. Modlitební knížku a růženec. NA Praha, ŘK, Spisy, inv. č. 376, kart. č. 368.

55 Rodiče museli hradit navíc pouze mimořádné výlohy např́ílad v prrípadě opravy oděvů a bot či nákupu školních pomůcek. (tamtéž)

56 Seznam dobrodinců hradčanské serafínské školy uveden in: NA Praha, ŘK, Spisy, inv. č. 376, kart. č. 368. Mezi nimi lze najít především církevní instituce, například benediktínské emauzské opatství, které ročně přispívalo 5000 Kčs, a římskokatolické farnosti měst (Brno, Kolín, Roudnice, Mělník atd.), kde fungovaly kapucínské kláštery (včetně i nejbližších okolních farností - Zhoř u Jihlavy atd.), v jejichž obvodu kapucíni (někdy i samotní diecézní kněží) organizovali sbírky na podporu serafínských škol.

57 Prostředky na provoz serafínských škol v tehdejším Československu mimo jiné zasílalo i římské ústředí řádu, např́klad v roce 1927 na tento účel odeslalo 2200 švýcarských franků a 10000 italských lir. (tamtéž)

58 Např́íklad v roce 1932/1933 byly př́ijmy školy za školné 2520 Kčs, ale vydání (dle účetní bilance sepsané V. Rabasem) za běžný provoz byla ve výši 45439 Kčs 30 halî̌ů. Tento účet mj. dokazuje, že kapucíni měli při škole obstojně vybavený př́rodovědecký kabinet, pro nějž opatřovali pravidelně chemikálie, mikroskopy, botanické nářadí atd., a velmi slušnou žákovskou knihovnu, do níž pravidelně přikupovali knihy. Kromě toho kapucíni nezapomínali ani na reklamu školy, když si pravidelně platili inzerci v tiskovinách. Největší položkou v účtu byla platba za lékařskou péči poskytnutou studentům, která činila 9920 Kčs. Mezi vydáními jsou i osobní vydání prefekta školy, tj. V. Rabase, ve výši 1556 Kčs (největší položkou bylo pořízení nových kamen do cely za 480 Kčs). (tamtéž) Náklady školy byly ještě větší v letech, kdy probíhaly stavební úpravy při škole, např́íklad v letech 1929 a 1930 kapucíni zaplatili 18995 Kčs 82 halírũ za přestavbu spárny (tj. ložnice), umývárny a revitalizaci dvorku (účet opět vyhotovil V. Rabas). (tamtéž)

59 NA Praha, ŘK, Rkp, inv. č. 324-326, Účty chovanců serafínské školy Třebíč (1937-1942).

60 NA Praha, ŘK, Spisy, inv. č. 332, kart. č. 347; ZA Opava, pob. Olomouc, Kapucíni Olomouc, Knihy, inv. č. 32; tamtéž, Spisy, inv. č. 99, kart. č. 54; P. Matějka jako rok založení školy v Olomouci uvádí 1894 (P. MATĚJKA, Ne mečem a měšcem, s. 31), od něj tento údaj přebírá i M. Buben (M. Buben, Encyklopedie rádů, III/1, s. 388).

61 SOA Litoměřice, Kapucíni Most, Knihy, inv. č. 23-24.

62 NA Praha, $\breve{R K}$, Spisy, inv. č. 376, kart. č. 368.

63 Vybudování na tehdejší poměry velmi moderní školy (viz architektonická dokumentace) při třebíčském klášteře vyšlo na 357000 Kčs (jednalo se totiž o zcela nové křídlo kláštera) a bylo hrazeno i ze sbírky určené na vybudování teologického učiliště v Olomouci, což bylo dáno tím, že zdejší serafínská škola mu musela ustoupit. NA Praha, ŘK, Spisy, inv. č. 597, kart. č. 453; tamtéž, Rkp., inv. č. 309; MZA Brno, E 37, Kapucíni Třebíč, inv. č. 74. Kapucíni po roce 1989 klášter restituovali a v rámci tradice serafínské školy ho poté darovali brněnskému biskupství, které v jeho budovách provozuje katolické gymnázium.

64 Následně byla česko-moravská provincie v roce 1935 přejmenována na československou, od níž se po podepsání Mnichovské dohody oddělily kláštery nacházející se na území Sudet, které vytvořily samostatný generální komisariát. Ten byl oficiálně zř́zen dne 30.12. 1938 a zanikl po skončení války, konkrétně dne 28. 5 . 1945, kdy zdejší kláštery byly znovu připojeny k česko-moravské provincii (nikoliv tedy k československé). Se vznikem slovenského státu v roce 1939 byly totiž od československé provincie de facto odděleny zdejší 
v době největšího rozmachu studovalo až 146 studentů zároveň, ${ }^{65}$ sehrály důležitou roli při obnově provincie v první polovině 20. století. V roce 1948 měl kapucínský řád 69 kněží a jen 15 z nich nebylo absolventy serafínských škol. S nástupem komunistického režimu bylo ukončeno fungování serafínských škol v Československu. Ve světě, hlavně ve Francii a Nizozemí, se serafínské školy udržely až do dnešní doby. ${ }^{66}$

Studenti serafínských škol byli v první a druhé třídě vyučováni v klášteře a přitom byli zapsáni jako privatisté na gymnáziu s právem veřejnosti, například hradčanští chovanci docházeli ke zkouškám na arcibiskupské gymnázium v Bubenči a třebíčští pak na jezuitské gymnázium na Velehradě. Počínaje třetím ročníkem již navštěvovali pouze veřejné gymnázium a v kapucínském klášteře tedy bydleli jen jako na internátě. Po ukončení pátého ročníku (kvinty) se chovanec stával členem řádu jako novic (noviciát tedy absolvovali při šestém ročníku gymnázia), což znamená, že studenti na serafínské škole nedokončili celé středoškolské studium bez toho, aby vstoupili do řádu. ${ }^{67}$ Poslední dvě gymnaziální třídy, tj. sedmý a osmý ročník, se klerikům započítával již do filozofického studia, přičemž ho budoucí kapucínští kněží absolvovali od roku 1922 až do roku 1938 téměř výhradně v zahraničí (což zvyšovalo nejen jejich jazykové dovednosti, ale i kulturní rozhled), a to při filozofických řádových studiích v belgickém Aalstu, nizozemském Breust-Eysdenu nebo švýcarském Stansu. To souvisí s nástupem italského generálního komisaře Pacifika Nanniho $(1872-1959)^{68}$ do čela česko-moravské provincie. ${ }^{69}$

V. Rabas působil jako prefekt serafínské školy fungující při hradčanském konventu až do roku 1939, ${ }^{70}$ přičemž školu nejen řídil, ale zároveň na ní i vyučoval (studenty v prvním

kláštery v Bratislavě a Pezinku, které vytvořily vlastní komisariát (de iure ustanoven 10. 4. 1942). Ten však se skončením 2. světové války nebyl připojen zpět a v roce 1987 byl povýšen na samostatnou provincii. Od roku 1997 oficiální název kapucínské provincie v České republice zní Provincie kapucínu v ČR. Ladislav TKAČík, Kapucíni na Slovensku, Bratislava 2017, s. 57-77; M. BuBEN, Encyklopedie řádi̊, III/1, s. 388-391.

65 Tohoto vrcholu dosáhli kapucínské serafínské školy v roce 1937, kdy při tř̌ebíčské působilo 52, při hradčanské 45, mostecké 33 a bratislavské 16 studentů. NA Praha, ŘK, Spisy, inv. č. 376, kart. č. 368. V rámci absolutních čísel lze uvést, že například olomouckou serafínskou školou od roku 1896 do roku 1936 prošlo celkem 203 studentů, $\mathrm{z}$ toho 66 jich vstoupilo do řádového noviciátu. Nejvíce studentů studovalo na olomoucké škole v roce 1924, a to 28. NA Praha, RK, Spisy, inv. č. 332, kart. č. 347. Většina studentů serafínských škol měla jako rodnou řeč češtinu, ti navštěvovali školy při klášterech v Olomouci, Praze a Třebíči. Výjimkou byly serafínské školy v Mostě, kde se vyučovalo německy, a v Bratislavě, kde byla užívaná především slovenština.

66 P. MATĚJKA, Ne mečem a měšcem, s. 33.

67 Pokud se jedinec nerozhodl pro vstup do řádu, byl absolventem pouze pěti ročníků gymnázia, které samozřejmě mohl dokončit, ale již nebydlel při studiu v kapucínském konventu. Kromě toho měli kapucíni (prefekt serafínského ústavu) právo vyloučit chovance ze studia na serafínské škole, a to z důvodu nedostatečných studijních výsledků, neplacení školného či neuspokojivého chování. Např́íklad v červnu 1936 V. Rabas propustil $\mathrm{z}$ hradčanské školy 8 žáků s tímto odůvodněním: $3 \times$ pro slabé studijní nadání, $3 \times$ pro neuspokojivé chování, $1 \times$ pro neplacení školného a $1 \times$ pro naprostou lenost. NA Praha, ŘK, Spisy, inv. č. 376, kart. č. 368 . V ř́ijnu 1935 zase bylo ukončeno studium dvěma chovancům z olomoucké školy, a to z důvodu nepřístojného chovaní při společném koupání. NA Praha, ŘK, Spisy, inv. č. 332, kart. č. 347.

68 Pacifik Nanni, křestním jménem Tommaso, narozen 12.9. 1872 v Monteboaggine, obláčka 6. 1. 1888, věčné sliby 14. 7. 1892, v česko-moravské provincii působil jako generální komisař (1922-1926) a mimořádný generální vizitátor (1926-1937). Dále doložen jako provinční ministr v domácí piceanské provincii (1919-1922, 1937-1940, 1946-1949). Zemřel 15. 2. 1959 ve Fano. Lexicon Capuccinum, s. 235, 1862; P. MATĚJKA, Seznam provinciálì, s. 319.

69 Viz stanovy hradčanské serafínské školy (z roku 1926). NA Praha, ŘK, Spisy, inv. č. 376, kart. č. 368; Srov. P. MATĚJKA, Ne mečem a měšcem, s. 34.

70 KPK Praha, sign. PK 00474, Catalogus Ordinis Minorum S. P. Francisci Capucinorum Almae Provinciae Bohemo-Moravae dispositus mense Augusto 1930, s. 5; sign. PK 00475, Catalogus Ordinis Minorum S. P. Francisci Capucinorum Almae Provinciae Bohemo-Moravae dispositus mense Martio 1933, s. 5; NA Praha, 
a druhém ročníku), konkrétně latinu, řečtinu, němčinu a dějepis. Kromě toho organizoval i slavnosti na škole, např́iklad napsal divadelní hru o dvou dějstvích s názvem Bojem $k$ vítězství, kterou studenti hradčanské serafínské školy sehráli v roce 1928 při př́ležitosti jmenin prezidenta Československé republiky. ${ }^{71} \mathrm{~V}$ době svého působení ve funkci prefekta hradčanské serafínské školy V. Rabas mj. postoupil též v řádové hierarchii, jelikož byl roku 1935 zvolen provinčním definitorem, přičemž v této funkci je doložen až do roku 1945.72

Od září 1939 došlo ke spojení pražské a třebíčské serafínské školy v důsledku přeložení teologického studia z Olomouce do Prahy (Hradčany), ${ }^{73}$ díky čemuž se V. Rabas na krátko přesunul do Třebíče, kde působil též jako ředitel serafínské školy. ${ }^{74} \mathrm{~V}$ červnu 1940 byl však již přeložen do olomouckého kláštera, ${ }^{75}$ kde se stal lektorem zdejšího řádového filozofic-

К̌K, Spisy, inv. č. 30, kart. č. 138, Catalogus Ordinis Minorum S.P. Francisci Capucinorum Almae Provinciae Bohemo-Moravae pro Anno Domini 1931, fol. 1r; tamtéž, Familiae Domorum post Congregationem diebus 17 et 18. Augusti 1936 habitum, fol. 1r; tamtéž, Familiae Domorum mense Decembri 1937, fol. 1r; tamtéž, Catalogus Ordinis Fratrum Minorum Capuccinorum Provinciae Nostrae Dispositus ad Finem Anni 1939, s. 4.

71 NA Praha, ŘK, Spisy, inv. č. 376, kart. č. 368.

72 NA Praha, RK, Spisy, inv. č. 30, kart. č. 138, Familiae Domorum post Congregationem diebus 17 et 18 . Augusti 1936 habitum, fol. 1r; tamtéž, Familiae Domorum mense Decembri 1937, fol. 1r; tamtéž, Catalogus Ordinis Fratrum Minorum Capuccinorum Provinciae Nostrae Dispositus ad Finem Anni 1939, s. 4; tamtéž, Familiae Domorum die 14. Iulii 1942, fol. 1r; tamtéž, Familiae Domorum die 17. Augusti 1943, fol. 1r; KPK Praha, sign. PK 00665, Catalogus Ordinis Minorum S. P. Francisci Capuccinorum Provinciae Bohemo-Moravae pro Anno a Christo Nato 1944, fol. 7r; tamtéž, Dispositio Patrum et Fratrum O. F. M. Capucinorum Prov. Bohemo-Moraviae facta in congregatione Olomutii die 12. Iulii A. D. 1945, fol. 1r. Poslední výroční katalog, který V. Rabase uvádí ve funkci provinčního definitora je z července 1945. Ten byl vydán po provinčním congregatiu uskutečněném dne 12. 7. 1945 v Olomouci. Srov. P. MATĚJKA, Seznam provinciáli̊, s. 321-323.

73 Výše jsme uvedli, že v česko-moravské provincii ve 20. letech chybělo řádové filozofické studium, které bylo tř́leté, a teologické studium, jehož absolvování trvalo čtyři roky. To byl i jeden z důvodů, proč protokol z proběhlé generální vizitace (z roku 1922) byl k vedení tehdejší česko-moravské provincie tolik kritický, což $\mathrm{v}$ konečném důsledku vedlo k uvalení nucené správy na provincii ve 20. a 30. letech, kdy v jejím čele stál z Říma dosazený komisař P. Nanni. Po jeho př́íchodu do provincie (1922) kandidáti kněžství studovali téměř výhradně v zahraničí. Ve 30. letech pak bylo rozhodnuto o vybudování vlastního domácího teologického studia při olomouckém klášteře, na jehož budovu (jednalo se o zcela nové křídlo) se peníze sháněly formou veřejné sbírky od října 1931. Do roku 1935, kdy bylo teologické studium otevřeno, se podařilo shromáždit celkem 1203605 Kčs, 23 halírù. Stejně jako v případě serafínských škol byly sbírky realizovány především ve farnostech, kde fungoval kapucínský klášter. NA Praha, ̌̌K, Rkp, inv. č. 309. Prvním ředitelem teologického studia v Olomouci byl hostující kapucín z pařížské provincie Appolinaire Quinquis (†1966). Teologické učiliště při olomouckém konventu fungovalo až do roku 1939, kdy bylo přeloženo do Prahy na Hradčany, kde mu byly vyhrazeny prostory zdejší serafínské školy. Na jeho místě v Olomouci pak bylo otevřeno filozofické studium, které tak nemuselo (vzhledem k politickým událostem ani nemohlo) probíhat v zahraničí. NA Praha, ŘK, Spisy, inv. č. 333, kart. č. 347. Srov. P. MATĚJKA, Ne mečem a měšcem, s. 34-37. K řádovým filozofickým a teologickým studiím v Československu v letech 1918-1950 blíže Eva ZavadiLovÁ, Výuka a vyučujíci kanonického práva na řádovém teologickém učilišti Kongregace Nejsvětějšího Vykupitele v Obořišti u Dobřiše v letech 1918-1950, Disertační práce, Cyrilometodějská teologická fakulta Univerzity Palackého v Olomouci, Olomouc 2019, s. 34-75.

74 Archiv Farního úřadu Třebíč-Jejkov, Kniha pamětni fary v Třebíči na Jejkově a spolu kapucínského kláštera od roku 1899 počinaje, s. 27 (bez signatury). Za zprostředkování pramene tímto děkujeme P. Vojtěchu Loubovi. Serafínská škola v Třebíči během 2. světové války fungovala jen do roku 1941, kdy byly její budovy zabrány Z nařízení Zemského úřadu v Brně (15. 12. 1941). Až do roku 1947 budova sloužila okresní nemocnici a bylo při ní ORL a oční oddělení. Poté byla činnost serafínské školy ve školním roce 1947/48 obnovena, ale záhy po únoru 1948 došlo k jejímu definitivnímu uzavření. Srov. Monika NovÁKovÁ, Kapucínský klášter a farnost Trebič-Jejkov v letech 1899-2000, Bakalářské práce, Pedagogická fakulta Masarykovy univerzity, Brno 2011, s. 47-48.

75 Familiae Domorum die 1. Augusti 1941, fol. 1r; srov. Catalogus Cleri Archidiocesis Olomucensis Anno reperatae salutis 1941, Olomucii 1941, s. 50. 
kého studia. ${ }^{76} \mathrm{~V}$ Olomouci pak prokazatelně pobýval až do července $1945,{ }^{77}$ přičemž zároveň zastával post vyučujícího (církevní dějiny, patrologii, archeologii a pastorální teologii) na zdejším arcidiecézním bohosloveckém učilišti ${ }^{78}$ a zpovědníka při místních komunitách Kongregace milosrdných sester III. řádu sv. Františka (tzv. opavské františkánky). ${ }^{79}$

$\mathrm{S}$ koncem druhé světové války končí i činnost $\mathrm{V}$. Rabase v rámci kapucínského řádu, na vlastní žádost se rozhodl z něj vystoupit. Motivace a okolnosti, které ho k tomuto kroku vedly, prameny nesdělují. Nicméně od podzimu 1945 prokazatelně působil V. Rabas mimo kapucínské komunity, když byl nejprve k 15. 9. ustanoven kooperátorem $v$ Jevíčku (děkanát Velké Opatovice, v olomoucké arcidiecézi), ${ }^{80}$ a následně se stal administrátorem v Březové nad Svitavou (děkanát Svitavy, v olomoucké arcidiecézi), což je doloženo na základě jeho žádosti z 24. 12., v níž žádá o posouzení své disertační práce ${ }^{81}$ s názvem Podobenství o marnotratném synu - rozbor kritický, literární a bohovédný. ${ }^{82}$ Po konci války se V. Rabas totiž rozhodl získat doktorát $\mathrm{z}$ teologie, žádost o připuštění $\mathrm{k}$ př́sným zkouškám $\mathrm{z}$ bohovědy na Cyrilometodějské bohoslovecké fakultě v Olomouci oficiálně podal již 10. 7.83 Posudky s připomínkami ke své disertaci dle podacího protokolu teologické fakulty si převzal 25. 3. $1946{ }^{84}$ Doktorské studium pak zakončil úspěšnou obhajobou práce a složením státnic dne 30.1.1947.85

76 Řádové studium filozofie v Olomouci probíhalo od roku 1939/1940, ale už v roce 1942 bylo přeloženo do Opočna, kam se v důsledku zabrání hradčanské kláštera německou okupační mocí (fungoval zde trestní tábor pro dezertéry z ruské fronty) přemístilo ve stejném roce i teologické studium. Při obou studích však byli pouze ti kapucíni, kteří nepodléhali totálnímu nasazení. V roce 1942 bylo v Německu takto nasazeno 11 kleriků-studentů. V roce 1945 se řádová studia vrátila do Prahy (teologie) a Olomouce (filozofie) a fungovala zde až do osudného roku 1950, kdy byly kláštery v Československu uzavřeny. Po roce 1989 již nebyla řádová studia v provincii obnovena. NA Praha, ŘK, Spisy, inv. č. 333, kart. č. 347; P. MATĚJKA, Ne mečem a měšcem, s. 34-37.

77 Familiae Domorum die 14. Iulii 1942, fol. 1r; Familiae Domorum die 17. Augusti 1943, fol. 1r; Catalogus Cleri Archidiocesis Olomucensis 1943, Olomucii 1943, s. 123; Catalogus Ordinis Minorum S. P. Francisci Capuccinorum Provinciae Bohemo-Moravae pro Anno a Christo Nato 1944, fol. 7r; Dispositio Patrum et Fratrum O. F. M. Capucinorum Prov. Bohemo-Moraviae facta in congregatione Olomutii die 12. Iulii A. D. 1945, fol. 1r.

78 ABS, sbírka Správa vyšetřování STB - vyšetřovací spisy (V), arch. č. V-2309 MV, složka V_2309_MV_obalka_02, scan 0091. Cyrilometodějská bohoslovecká fakulta v Olomouci byla stejně jako dāšš české veřejné vysoké školy za nacistické okupace uzavřena, proto arcibiskup L. Prečan nechal zř́́dit soukromý diecézní seminář, na němž vyučoval spolu s dalšími olomouckými řeholníky V. Rabas, aby tak zachoval kontinuitu ve výchově kněžského dorostu. Miloslav PossL, Teologická fakulta v Olomouci (1860-1946), in: Jiř́ Fiala Zdeněk Kašpar - Leoš Mlčák - Miloslav Pojsl - Pavel Urbášek (edd.), Univerzita v Olomouci (1573-2009), Olomouc 2009, s. 85-97, s. 94.

79 Catalogus Ordinis Minorum S. P. Francisci Capuccinorum Provinciae Bohemo-Moravae pro Anno a Christo Nato 1944, fol. 7r. K olomouckým klášterům této kongregace viz Dušan FolTÝn, Encyklopedie moravských a slezských klášterio, Praha 2005, s. 511, 522-523.

80 ABS, sbírka Správa vyšetřování STB - vyšetřovací spisy (V), arch. č. V-2309 MV, složka V_2309_MV_obalka_02, scan_0092.

81 ZĀ Opava, pob. Olomouc, Univerzita Palackého Olomouc, Knihy, inv. č. 961, Podací protokol teologické fakulty 1945-1947, s. 67 (č. j. 427).

82 Práce je dochována: tamtéž, inv. č. 563. Její rozsah je 122 stran, podle citovaných autorit Rabas vycházel zejména z německy píšících teologů (jak katolické, tak i protestantské konfese), např́klad k jeho zdrojům patřili: Joseph Knabenbauer (1839-1911), Rudolf Kittel (1853-1929), Leopold Fonck (1865-1930), Edmund Kalt (1879-1943), Hilarius Felder (1867-1951) či Theodor Innitzer (1875-1955).

83 Tamtéž, Knihy, inv. č. 961, Podací protokol teologické fakulty 1945-1947, s. 12 (č. j. 141).

84 Tamtéž, s. 94 (č. j. 755).

85 Tamtéž, inv. č. 368, Kniha protokolů o vykonaných rigorózních zkouškách teologické fakulty (1835-1949), záznam z 30. 1. 1947 (nepaginováno); Tamtéž, Knihy, inv. č. 962, Podací protokol teologické fakulty 1947-1948, s. 10 (č. j. 502). 
Správcem farnosti v Březové nad Svitavou byl následně až do konce srpna $1946,{ }^{86}$ poté odešel do své rodné litoměřické diecéze, kde byl ustanoven profesorem morálky na zdejším bohosloveckém učilišti (viz dále). Exklaustrační dekret byl V. Rabasovi vydán generálním ministrem kapucínského řádu dne 11. 2. 1946 v Ř́mě. ${ }^{87}$

V době svého působení v kapucínském řádu se kromě pedagogické práce věnoval spisovatelské činnosti, a to zejména rádovému dějepisectví. V. Rabas kromě jiných řádových funkcí totiž působil ve 20. a 30. letech jako dlouholetý knihovník kapucínské provinční knihovny v Praze na Hradčanech, ${ }^{88}$ díky čemuž byl výborným znalcem zde uložených provinčních letopisů $\mathrm{z} 18$. století, ${ }^{89}$ které se staly primárním zdrojem informací $\mathrm{k}$ jeho historickým publikacím. V. Rabas totiž své výzkumy nejdříve zveřejňoval v řadě dílčích studiii, ${ }^{90} \mathrm{a}$ teprve následně je shrnul ve své životní monografii o dějinách kapucínského řádu v českých zemích v raném novověku. ${ }^{91}$ Jeho dílo je však nejen kvůli výchozím pramenům, tj. provinčním letopisům, které nepodrobil řádné kritice, velice subjektivní, z pochopitelných důvodů tak straní kapucínskému řádu. ${ }^{92}$ Přesto i pozdější autoři (Bernard Bartoň, ${ }^{93}$

86 Catalagus cleri Archidiocesis Olomucensis, Olomucii 1946, s. 64; ABL, Josef Rabas, sign. CH-21, Domovský list F. Rabase z Březové nad Svitavou z 12. 7. 1946.

87 Informace uvedena v materiálech týkajících se jeho ustanovení kaplanem v Církvicích (viz dále). ABL, Biskupská konzistoř 1941-1990; sign. II-A-1 - beneficia, Církvice; P. Matějka chybně uvádí jako rok odchodu V. Rabase z kapucínského řádu 1948. P. MATĚJKA, Seznam provinciálů, s. 323. Vzhledem k Rabasovu vystoupení z kapucínského řádu lze zároveň předpokládat jeho inkardinaci do litoměřické diecéze, př́íslušné dokumenty se však nepodařilo dohledat.

$88 \mathrm{~K}$ této instituci blíže Marek BRČÁK, Kapucinský rád a jeho působení v Čechách a na Moravě (1673-1783), Disertační práce, Filozofická fakulta Univerzity Karlovy, Praha 2019, s. 33-34.

89 K provinčním letopisům česko-moravské provincie TY̛ž, Annales Patrum Capucinorum provinciae Boemiae: Písemné prameny $k$ dějinám kapucinského řádu v českých zemích v 17. století a možnosti jejich využití, Historica Olomucensia 41, 2012, s. 143-169.

90 Vavřinec RABAs, Prvopočátky řádu kapucinského, Časopis katolického duchovenstva (dále jen ČKD) 71, 1930, s. 63-71, 569-609; TY̌ž, Řád kapucinský a jeho působení v Čechách v 17. století, ČKD 77, 1936, s. 217-238, 329-349, ČKD 78, 1937, s. 25-41, s. 393-406; TÝž, Kapucíni a katolická restaurace v Čechách, ČKD 79, 1938, s. 16-38; т̛́ž, Valerianus de Magni, nejslavnějši muž českomoravské provincie, ČKD 79, 1938, s. 289-338; тÝž, Stručný prehled činnosti kapucinů v XVII. století, ČKD 79, 1938, s. 369-384. Kromě toho ještě napsal dvě práce menšího rozsahu: TÝž, Prưvodce po Loretě v Praze na Hradčanech, Praha 1937 (německy: TÝž, Führer durch die Kirche, den Kreuzgang u. die Loretokapelle der P. P. Kapuziner in Prag am Hradschin, Prag 1939); TÝž, Svatý Vavřinec z Brindisi, zakladatel Česko-moravské provincie rádu kapucinského, Olomouc 1941.

91 TÝž, Řád kapucínský a jeho působení v Čechách v 17. století, 1.c. Kniha se zabývá především událostmi spojenými s uvedením řádu do českých a rakouských zemí (1599-1600), dále popisuje vnější rozvoj česko-rakouské provincie, přičemž velká pozornost je věnována okolnostem vedoucím $\mathrm{k}$ jejímu rozdělení na česko-moravskou a rakouskou provincii (1673). V dalších kapitolách V. Rabas uvádí základní informace k jednotlivým kapucínským konventům (rok založení, hlavní fundátory atd.) nacházejícím se v českých zemích. Autor též cástečně nastiňuje vnitřní poměry v provincii či se zmiňuje o nejvýznamnějších „českých“ kapucínech. V neposlední řadě shrnuje veškerou činnost řádu v tomto časovém úseku.

92 Zejména je to patrné v pasážích týkajících se rekatolizační činnosti a sporů, jejichž aktéry byl kapucínský rád. Zde si musí být čtenář vědom toho, že text obsahuje velkou dávku stylizace, dalo by se dokonce říci romance, jelikož kapucíni jsou v nich líčeni velice neobjektivně. Rabasovo dílo vlastně zrcadlí barokní tradici rádu, která se tak stala ve 20. století (částečně i dnes) v kolektivní paměti provincie dosud živou. M. BRČÁk, Působení kapucinského řádu (v tisku).

93 Bernard Bartoň, křestním jménem Josef, narozen 4. 1. 1920 v Mořkově, obláčka 1. 1. 1937, věčné sliby 8. 9. 1941, kněžské svěcení 7. 11. 1943, byl absolventem kapucínské serafínské školy v Olomouci. Po druhé světové válce v řádu působil jako lektor církevních dějin a novicmistr. Poté, co proběhla Akce K, byl odveden jako voják k PTP, zde v roce 1953 zatčen z politických důvodů, odsouzen ke třem letům vězení. Po propuštění pracoval jako automechanik, od roku 1968 směl opět vykonávat kněžské povolání. V roce $1980 \mathrm{~B}$. Bartoňovi vyšla samizdatově kniha: Bernard BARTOŇ, Dějiny řádu kapucínského se zréetelem na českomoravskou provincii, 1980 (strojopis, KPK Praha, sign. PK 06164). Po sametové revoluci byl členem kapucínské řeholní 
Milan Buben, Pacifik Matějka) píšící o kapucínském řádu v českých zemích vycházeli především z něj, aniž by podrobili jeho texty nějaké reflexi.

V. Rabas se v rámci svých literárních aktivit kromě řádové historiografie věnoval i teologii. Vedle již uvedené disertační práce sepsal dvě zpovědní zrcadla, ${ }^{94}$ která svým duchem odpovídají tehdejší „,konzervativní“ dobové zbožnosti. Tato díla tedy naznačují, že V. Rabas se jistě neřadil k , ,liberálním“ teologům požadujícím změny ve smyslu myšlenek „Aggiornamento“ přijatých později druhým vatikánským koncilem. ${ }^{95}$

Jak už bylo uvedeno výše, F. Rabas se vrátil do rodné diecéze v záŕí 1946, tj. v době, kdy do ní přicházela i řada dalších kněží z různých koutů Československa, kteří se pokoušeli zacelit zásadní rány v pastoraci způsobené odsunem německých duchovních. ${ }^{96}$ Pokud ve své studii zabývající se př́íchodem nových kněží do litoměřické diecéze po druhé světové válce historik Michal Sklenář shrnuje osobní motivace těchto duchovních $\mathrm{k}$ přesunu jako kombinaci „viry, presvědčení, osobnich predpokladů, materiálního zázemí či snah o změnu“, 97 podchycuje nepochybně také Rabasův př́ípad. Jeho motivací sice nebylo jako u mnohých kněží ,budovat a obnovit české pohraničí svoji praci", 98 v tomto směru se ostatně mohl angažovat i v Březové nad Svitavou, ale spíše se jednalo o osobní rovinu spojenou s odborným profesním uplatněním. F. Rabas totiž dle své pozdější výpovědi vyhověl v červenci 1946 pozvání tehdejšího litoměřického biskupa Antona Aloise Webera, ${ }^{99}$ aby ,přijel do Litoměřcic a zúčastnil se výchovy kněžského dorostu“. ${ }^{100}$ Nejednalo se jistě o pozvání náhodné - sekretářem biskupa Webera byl od roku 1937 Rabasův bratr Josef, v jehož domácnosti od konce 30. let žily také matka Rosa a sestra Anna. ${ }^{101}$ Ta však byla v srpnu 1946 spolu s bratrem Josefem odsunuta do Bavorska, ${ }^{102}$ a tak v Litoměřicích (v domě č. p. 2 na Dómském náměstí103) se svou matkou zůstal právě František Rabas. To ostatně potvrzuje i znění dekretu, který 18. 9. 1946 vydala litoměřická biskupská konzistoř a jímž F. Rabase ${ }^{104}$, ,t. č. v Litoměřicích“ jmenuje ,zatímním profesorem a zástupcem profesora morálky“" na litoměřickém bohosloveckém učilišti. ${ }^{105}$ Zároveň lze poukázat i na to, že do

komunity v Olomouci. Zemřel dne 11. 10. 2000 v Olomouci. Pacifik MATĚJKA, Literárně činní členové a přiznivci kapucínského ř́du v Čechách, Paginae historiae 18, 2010, s. 217-264, s. 252-253.

94 V. Rabas. Myšlenky pro zpovědníky k poučení kajícníkù (strojopis, KPK Praha, sign. PK 05801a) a Zpovídáme německy (zlomek nedokončeného rukopisu, strojopis, KPK Praha, sign. PK 05801b).

95 Viz Stanislav BALíK - Jiří Hanuš, Letnice dvacátého století. Druhý vatikánský koncil a české země, Brno 2012.

${ }^{96}$ Ke stavu a problémům litoměřické diecéze po roce 1945 podrobněji M. SKLENÁŘ, „Dávám se cele k disposici k pastoraci v pohraniči “.

97 Tamtéž, s. 157.

$98 \mathrm{~K}$ těmto př́padům Tamtéž, s. 155.

99 Byt' jeho jurisdikce byla v této době fakticky minimalizována; srov. Zlatuše KuKÁNovÁ, „Nepřekážel jsem přirozenému běhu věcí v ničem “. K rezignaci litoměřického biskupa Antonína Aloise Webera, Porta Bohemica. Sborník historických prací 9, 2019, s. 137-168, zejména s. 140.

100 ABS, sbírka Správa vyšetřování STB - vyšetřovací spisy (V), arch. č. V-2309 MV, složka V_2309_MV_ mapa_02, scan 0051 (výpověd' Františka Rabase z 31. 10. 1953).

101 Tamtéž, složka V_2309_MV_podsvazek_3, scan 0086 (výpověd' Rosy Rabasové z 20. 4. 1953).

102 Tamtéž; ABL, Biskupská konzistoř 1941-1990, sign. III-A-1 - personália, Josef Rabas.

103 Bydliště je doloženo v korespondenci bratrů Rabasů, která se nachází v jejich osobních složkách vedených při litoměřické biskupské konzistoři (ABL, Biskupská konzistoř 1941-1990, sign. III-A-1 - personália, Josef a František Rabas) a v osobním fondu Josefa Rabase (ABL, Josef Rabas, sign. CH-39).

104 V záhlaví dekretu je uvedeno „Vavřinec František Rabas, kněz řádu kapucínského“, přičemž poslední dvě slova byla následně (snad právě až adresátem) přeškrtnuta.

105 ABS, sbírka Správa vyšetřování STB - vyšetřovací spisy (V), arch. č. V-2309 MV, složka V_2309_MV_obalka_2, scan 0067 . 
litoměřické diecéze $\mathrm{v}$ této době odcházela řada jen nedávno ze svých řeholních řádů uvolněných kněží nebo také řeholníků, čelících ve svých společenstvích určitým problémům (důvody Rabasova odchodu od kapucínů však prameny nesdělují, viz výše). ${ }^{106}$ Zdá se však pravděpodobné, že jeho motivace měla spiše onen zmíněný osobní charakter, který se zde skloubil s možností dalšího pedagogického působení při formaci kněžského dorostu, které bylo F. Rabasovi zřejmě vlastnější, než běžná pastorace ve farnosti. V této souvislosti se může i krátkodobá administrace farnosti Březová v olomoucké arcidiecézi jevit spíše jako útěk z řádového prostředí než jako snaha zacelit mezeru ve farní správě.

Litoměřický kněžský seminář bylo potřeba po druhé světové válce znovu obnovit, jelikož v důsledku událostí z let 1938-1945 fakticky zanikl. ${ }^{107}$ Krizová situace litoměřické diecéze v pozdním jaru a létu 1945, kdy byl sídelní biskup A. A. Weber státními úřady zbaven jurisdikce a diecézi spravoval nově jmenovaný generální vikář české národnosti, již letitý farář z Kováně na Mladoboleslavsku Josef Kuška (1873-1953), nedovolovala řešit stav semináře, nehledě $\mathrm{k}$ malému počtu potenciálních alumnů. ${ }^{108}$ To se však mělo změnit od akademického roku 1946/1947, kdy měl být v Litoměřicích opětovně otevřen klasický diecézní kněžský semináŕ - jednalo se o jeden z dalších bodů poválečné obnovy litoměřické diecéze. ${ }^{109}$ Problémem však bylo jeho umístění, nebot' původní budova někdejší jezuitské koleje byla poničena bombardováním. ${ }^{110}$ Kuškův úmysl použít objekt bývalého diecézního ústavu pro hluchoněmé neuspěl, ${ }^{111}$ a tak se seminář nakonec provizorně nastěhoval do již z válečných let „osvědčeného“ (tehdy již bývalého) litoměřického kláštera boromejek (Vavřinecká ulice č. 13) a tři posluchárny byly umístěny v celách nedalekého kapucínského konventu, přesto však „místnosti pro profesorskou sborovnu, kabinety,

106 Některé př́ípady uvádí M. SkLenár̆, „Dávám se cele k disposici k pastoraci v pohraniči“", s. 147, 151.

107 Od podzimu 1938 studovali bohoslovci z české (později protektorátní) části diecéze v pražském arcibiskupském semináŕi, byt' naopak v Litoměřicích byli vzděláváni ještě alumni z části královéhradecké diecéze, která spadala do Sudetské župy. Seminaristé však (na rozdíl od vysvěcených kněží) podléhali vojenskému odvodu, a tak diecézní katalog z roku 1944 již neeviduje žádného studujícího bohoslovce. Seminář ostatně ztratil i svou budovu bývalé jezuitské koleje, krátce byl umístěn v biskupské rezidenci a od roku 1941 mu vzhledem ke klesajícímu počtu alumnů stačilo několik místností v litoměřickém klášteře boromejek ve Vavřinecké ulici; srov. Handbuch der Diözese Leitmeritz 1941 (stand vom 1. Jänner 1941), Leitmeritz [1941], s. 50-51; Personalangaben der Geistlichkeit der Diözese Leitmeritz (Stamd vom 1. Jänner 1944), Leitmeritz [1944], s. 3; J. RABAS, Biskup Anton Alois Weber, s. 89-90. Dějiny litoměřického kněžského semináře nejsou komplexně zpracovány a existující literatura se zabývá obdobím do počátku 20. století; srov. Hermann ZscноккE, Die theologische Studien und Anstalten der katholischen Kirche in Österreich, Wien - Leipzig 1894, s. 922-940; Alumnát litoměřický, in: Antonín Podlaha (ed), Český slovník bohovědný, I, Praha 1912, s. 335-337; Heinrich Donat, Das Priesterseminar in Leitmeritz, in: 1227-1927. Stadt Leitmeritz. Festschrift zur Feier des 700jährigen Bestandes als Stadt, Leitmeritz 1927, s. 119-123.

108 Ti, kteří studovali během války v Praze, tam také svá studia dokončovali; srov. dopisy některých bohoslovců studujících v Praze v ABL, Biskupská konzistoř 1941-1990, sign. I-A-5e - litterae dimissoriales et testimoniales.

${ }^{109} \mathrm{~K}$ tomu v širším kontextu M. SKLEnÁR̆, „Dávám se cele k disposici k pastoraci v pohraniči“", s. 142-144.

110 Nadto byl tento objekt ve vlastnictví Náboženského fondu, který se - po souhlasu biskupství - rozhodl budovu na tři roky pronajmout Sboru národní bezpečnosti pro výcvik jeho př́islušníků, zatímco měly probíhat př́islušné opravy; celá záležitost je přehledně shrnuta v ABL, Biskupská konzistoř 1941-1990, sign. I-A-5c - budova semináře, dopis J. Kušky Ministerstvu školství a osvěty z 21. 7. 1946.

111 Ústav, v němž o chovance rovněž pečovaly boromejky, zanikl zrejejmě v roce 1945, přičemž od 6. 9. téhož roku získal jeho budovu do nájmu Spolek pro péči o slabomyslné v Praze, který zde zř́́dil opatrovnu a školu pro mentálně postižené děti. Přestože J. Kuška dal řádnou výpověd' z této smlouvy, jejíž lhůta měla uplynout 31. 8 . 1946, zmíněný spolek toto nerespektoval s argumentem, že nemá pro chovance jiné prostory. Spor, který se pak táhl až do roku 1948 (viz dále), lze rekonstruovat z četné úřední korespondence v ABL, Biskupská konzistoř 1941-1990, sign. I-A-5c - budova semináře. 
knihovny a předepsané byty pro představené semináre a obsluhujicí sesterský personál úplně chybi" ${ }^{\prime \prime} .112$

Do tohoto skutečně provizorního ústavu, ${ }^{113}$ který měl 28 bohoslovců ve všech pěti ročnících, ${ }^{114}$ nastoupil F. Rabas k 1. 10. 1946 jakožto profesor morální teologie. ${ }^{115}$ Původ jeho kolegů z pedagogického sboru byl skutečně různorodý. Jednalo se bud' o mladé vzdělané kněze stojící na počátku své akademické dráhy, v níž později pokračovali na pražské, resp. litoměřické Cyrilometodějské bohoslovecké fakultě, ${ }^{116}$ či o jejich obdobně vzdělané vrstevníky, jimž následná totalita další profesní rozvoj neumožnila, ${ }^{117}$ př́padně o diecézní kněze ${ }^{118}$ bez zásadnějších zkušeností s obdobnými posty. ${ }^{119}$ Zásadní postavou byl nepochybně proslulý český katolický myslitel a zkušený pedagog Metoděj Habáň, OP (1899-1984), který se stal spirituálem semináře a vyučoval zároveň filozofii, logiku, experimentální psychologii a metafyziku. ${ }^{120}$

O samotném Rabasově pedagogickém působení v Litoměřicích, stejně jako o fungování celého tohoto semináře, nemáme v podstatě žádné informace. ${ }^{121}$ Jisté je pouze

112 Tamtéž, dopis seminárního rektora Miloslava Černého (1902-1976) technickému oddělení ONV v Litoměřicích z 24. 2. 1947.

113 Abychom byli přesní, je důležité odlišovat od sebe pojem kněžského semináře, tedy instituce, která vykonávala výchovu a formaci kněžského dorostu a v jejímž čele stál rektor, od tzv. bohosloveckého učiliště (někdy zvaného též teologický institut), tedy samotného školního zařízení, které poskytovalo chovancům semináře odborné vzdělání a vznikalo v těch biskupských městech, kde nesídlily teologické fakulty. V čele těchto učilišt' stáli jako direktoři vždy formálně diecézní biskupové, reálné vedení však spočívalo na děkanech. Obě instituce, které vesměs sídlily $\mathrm{v}$ jedné budově a byly $\mathrm{v}$ některých př́ípadech také personálně propojeny, ovšem často i z uvedených důvodů splývají při pohledu zvnějšku v jeden celek.

114 ABL, Biskupská konzistoř 1941-1990, sign. I-A-5a - představení semináře, dopis J. Kušky pražskému Zemskému národnímu výboru z 27. 12. 1946.

${ }^{115}$ Formálně byl jmenován „zatímním profesorem“ (ABS, sbírka Správa vyšetřování STB - vyšetřovací spisy (V), arch. č. V-2309 MV, složka V_2309_MV_obalka_2, scan 0067), v dalších dobových dokumentech však př́slušné adjektivum chybí - např̀. v žádosti o żpovědní jurisdikci podané na konzistoř 17. 10. 1946 je uváděn jako „profesor mravovědy v kněžském semináŕi v Litoměřicich“; srov. ABL, Biskupská konzistoř 1941-1990, sign. III-A-1 - personália, František Rabas.

${ }^{116}$ František Kotalík (1917-1993) - starozákonní biblistika, Jaroslav Kouřil (1913-1981) - pastorální teologie a sociologie.

117 Prokop Švach, OP (1907-1975) - novozákonní biblistika a řečtina, Josef Bat'ka (1901-1979) - patrologie.

118 Miloslav Černý (1902-1976) - rektor semináře, Václav Hataš (1914-1986) - vicerektor, profesor fundamentální teologie, František Ř́ha (1917-1995) - církevní dějiny.

119 Jména vyučujících včetně př́slušných předmětů jsou uvedena na základě unikátně dochovaného indexu tehdejšího bohoslovce Vladimíra Kusého (1911-1988). ABL, Vladimír Kusý, Liber testimonialis de frequentia et progressu in disciplinis theologicis auditoris Domini Vladimiri Kusý oriundi e Frenštát p/R Moravia inscripti in album instituti theologici diocesani Litomericensis (bez signatury). Informace o pedagogickém působení J. Bat'ky je doložena zatím jen jednou písemností. ABL, Biskupská konzistoř 1941-1990, I-A-3a - představení semináře, pozvání profesorů semináře na zasedání biskupské konzistoře (16. 10. 1946). Pro jmenování představených semináře srov. Ordinariátní list litoměřické diecése 10/1946, 1. 10. 1946, s. 82. Srov. V. NovotNÝ, Katolická teologická fakulta 1939-1990, s. 53.

120 ABL, Biskupská konzistoř 1941-1990, sign. I-A-5a - představení semináře, dopis J. Kušky pražskému Zemskému národnímu výboru z 27. 12. 1946; ABL, Vladimír Kusý, Liber testimonialis de frequentia et progressu in disciplinis theologicis auditoris Domini Vladimiri Kusý (...); Petr МАсек, Metoděj Habáň: učitel, filosof a svědek dvacátého století, Praha 2019, s. 99.

121 V obavě o jejich možné zneužití státní mocí F. Rabas při likvidaci litoměřického semináře v létě roku 1950 část písemností uschoval a část spálil (ABS, sbírka Správa vyšetřování STB - vyšetřovací spisy (V), arch. č. V-2309 MV, složka V_2309_MV_mapa_02, scan 0063 (výpověd' F. Rabase z 10.-12. 11. 1953). Tamtéž, složka V_2309_MV_mapa_02, scan 0088 (výpověd' F. Rabase z 16. 11. 1953), což dnešní podrobnější bádání značně komplikuje. 
to, že po formální rezignaci biskupa A. A. Webera v únoru $1947^{122}$ byl k 10. 3. téhož roku jmenován apoštolským administrátorem diecéze nový pražský arcibiskup Josef Beran (1888-1969). Ačkoliv jeho vliv na běžné fungování diecéze byl spíše okrajový, snad kromě jmenování Františka Vlčka (1903-1989) novým generálním vikářem, rozhodl 22. 7. 1948, že litoměřický diecézní kněžský seminář bude od akademického roku 1947/1948 sloučen s pražským. ${ }^{123}$ Tím se stal pedagogický sbor litoměřického bohosloveckého učiliště nadbytečným a byl rozpuštěn.

Na rozdíl od svých kolegů zůstal F. Rabas v Litoměřicích, a to nejen kvůli své matce, ale zřejmě i s ohledem na všeobecný nedostatek duchovních v diecézi, a 18. 9. 1947 byl se zpětnou účinností od 1. 9. jmenován kaplanem v Církvicích. ${ }^{124}$ Nakolik skutečně v této menší farnosti ležící u Labe mezi Litoměřicemi a Ústí nad Labem působil, když ta byla excurrendo spravována Josefem Hillem (1914-2002) z nedalekých Libochovan, ${ }^{125}$ nelze přesně zhodnotit. ${ }^{126}$ Domníváme se však, že se jednalo spíše o poskytnutí beneficiátního zajištění, přičemž lze předpokládat určité Rabasovo zapojení do činnosti konzistoře, která se $\mathrm{v}$ té době nacházela $\mathrm{v}$ personální krizi. ${ }^{127}$ Potvrzuje to především dopis generálního vikáře F. Vlčka na ministerstvo školství a osvěty z 3. 2. 1948, v němž žádá o ustanovení F. Rabase k litoměřické konzistorní kanceláři s platností již od 1. 12. 1947. ${ }^{128}$ Ten byl konzistorním referentem oficiálně nakonec jmenován k 15. 2. 1948. ${ }^{129}$

Nový litoměřický biskup Štěpán Trochta (1905-1974) byl intronizován 23. 11. 1947 a již krátce poté začal svou diecézi přetvářet, reformovat a uzpůsobovat novým potřebám. ${ }^{130}$ Jedním z prvních a zásadních kroků bylo navrácení diecézního kněžského semináře do Litoměřic od nového akademického roku 1948/1949. Konkurz na profesorská místa byl vyhlášen již v lednu 1948. ${ }^{131}$ Sídlem semináře se nakonec stal objekt bývalého diecézního ústavu pro hluchoněmé v Komenského ulici, ačkoliv vystěhování školy a ústavu, který zde provozoval Spolek pro péči o slabomyslné, bylo velmi komplikované a uskutečnilo se až díky intervenci ministra zdravotnictví, „vlasteneckého“132 kněze Josefa Plojhara

${ }^{122}$ Celý komplikovaný proces, který vyvrcholil 17. 2. 1947 prrijetím Weberovy rezignace Svatým stolcem, popsala Z. KuKÁNOVÁ, ,Nepřekážel jsem přirozenému běhu věcí v ničem “, s. 137-159.

123 Ordinariátní list litoměřické diecése 8/1947, 1. 8. 1947, s. 51; V. NovotnÝ, Katolická teologická fakulta 1939-1990, s. 53.

124 ABL, Biskupská konzistoř 1941-1990, II-A-1 - beneficia, Církvice; ABS, sbírka Správa vyšetřování STB vyšetřovací spisy (V), arch. č. V-2309 MV, složka V_2309_MV_mapa_02, scan 0097.

${ }^{125}$ Za zmínku v této souvislosti jistě stojí, že před F. Rabasem od 1. 2.1947 na stejném postu působil jeho kolega z učiliště J. Kouřil; ABL, Biskupská konzistoř 1941-1990, II-A-1 - beneficia, Církvice.

${ }^{126}$ Doklady o jeho pastoračním či jiném působení nebyly v různých dokumentech $\mathrm{ABL}$ dohledány, F. Rabase naprosto ignoruje i pamětní kniha církvické farnosti, byt' byla psána až do roku 1948; srov. ABL, Sbírka farních pamětních knih, Zirkowitzer Pfarrgedenkbuch, tom. II. (bez signatury).

127 Ta propukla po odsunu německých kanovníků v květnu 1946 a ke konsolidaci došlo až po nástupu Štěpána Trochty na litoměřický biskupsky stolec. ABL, Biskupská konzistoř 1941-1990, sign. I-A-3a - představení semináře, passim.

128 Tamtéž.

129 Ordinariátní list litoměřické diecése 2/1948, 15. 2. 1948, s. 12. Oficiální povolení k tomuto ustanovení vydal Zemský národní výbor v Praze 12. 4. 1948; srov. ABS, sbírka Správa vyšetřování STB - vyšetřovací spisy (V), arch. č. V-2309 MV, složka V 2309 MV mapa 02, scan 0065.

${ }^{130}$ První léta Trochtova litoměřického pūsobení se pokusil charakterizovat (byt' ne zcela komplexně) Petr ZeLINKA, ThDr. Štěpán kardinál Trochta (1905-1974), prvni tři roky jeho biskupské služby v Litoméricich, Poohří 5, 2015 (=Církev a společnost. Sborník z konference konané v Litoměřicích 16. a 17. října 2014), s. 158-177.

131 Ordinariátní list litoměřické diecése 1/1948, 15. 1. 1948, s. 5.

132 Bliže k této skupině kněží nakloněné politice komunistického režimu například Jaroslav CuHRA, Nejen ze života církví: Vznik Sdruženi katolických duchovnich Pacem in terris, Historický obzor 10/5-6, 1999, s. 128-131. 
(1902-1981), jehož v této věci oslovil př́mo Š. Trochta. ${ }^{133}$ Urychlená adaptace objektu byla možná jen díky četným brigádám bohoslovců i litoměřických farníků a byla zakončena vysvěcením seminární kaple sv. Jana Boska biskupem Trochtou při zahájení akademického roku 10. 10. 1948. ${ }^{134}$

Profesorský sbor nového litoměřického bohosloveckého učiliště z velké části kopíroval složení svého předchůdce z roku 1946/1947. ${ }^{135}$ Děkanem byl tentokrát jmenován J. Bat'ka, jehož v akademickém roce 1949/1950 nahradil právě F. Rabas, který zároveň znovu vyučoval pastorální a morální teologii a stal se také rektorem semináře. ${ }^{136}$ Rabas se rovněž aktivně podílel na celkové adaptaci budovy pro potřeby semináře, jak vyplývá zejména z obsáhlého rozhovoru, který na podzim 1948 poskytl Naši spolupráci, pastorační př́iloze litoměřického ordinariátního listu. Kromě popisu obtíží při vzniku semináře, který emotivně charakterizoval slovy „čím je srdce člověku, tím je pro diecési kněžský seminár““, nastínil i budoucnost této instituce. Vyjádřil nutnou potřebu kněží v obtížné pastoraci diecéze, nebot' ,jen svatý kněz něco vykoná v těchto těžkých a bouřlivých dobách“, přičemž však neopomněl připomenout nutnou celodiecézní podporu semináře ve hmotné rovině formou svépomoci každé farnosti (,třeba pod heslem: Každý katolík dá ročně aspoñ Kčs 2,- na seminár “") a v duchovní rovině uskutečněním „v každé farnosti aspoň jednou ročně den kř́žové výpravy modliteb za dorost kněžský, spojenýs celodenní adoraci Nejsvětějšsi svátosti a jinými pobožnostmi“ ${ }^{\text {“ }}{ }^{137}$ Kromě těchto deklarací však nejsme schopni Rabasovo působení př́mo v semináři detailněji poznat, a to i z důvodu nedochování pramenů.

Nejpozději od Trochtova nástupu do úřadu litoměřického biskupa působil F. Rabas na konzistoři jako referent. Postupně mu přibývaly, nepochybně na základě biskupovy důvěry, která se projevila především jmenováním do funkce rektora semináře, i další úřední posty. V lednu 1948 byl v rámci nově ustanoveného diecézního soudu jmenován ochráncem spravedlnosti a obhájcem manželského svazku a rovněž biskupským knižním cenzorem, ${ }^{138}$ k 1. 12. téhož roku prosynodálním examinátorem (tj. členem komise pro farářské zkoušky), ${ }^{139}$

133 ABL, Biskupská konzistoř 1941-1990, sign. I-A-5c - budova semináře, četná korespondence z jara a léta 1948.

134 V. NovotnÝ, Katolická teologická fakulta 1939-1990, s. 53. Informaci o zasvěcení seminární kaple srov. Ze semináre, Naše spolupráce. Stálá pastorační př́loha Ordinariátního listu litoměřické diecése 2/1949, 1. 2. 1949, (nepaginováno, autor neuveden).

135 Z nových osobností je potřeba uvést zejména následující: Vojtěch Martinů (1911-1955) - dogmatická teologie, Josef Honzík (1916-1981) - etika a sociologie, Štěpán Vandík, SDB (1916-1971) - orientální teologie; Václav Červinka (1922-2007) - asketická teologie (nejisté jmenování), Bernardin Jan Skácel, OP (1884-1959) - filozofie, Ladislav Pokorný (1915-2000) - pedagogika a katechetika, Jan Marek, SDB (1922-1993) - latina, Josef Pietschmann (1906-1950) - církevní zpěv. Ordinariátní list litoměřické diecése 10/1948, 1. 10. 1948, s. 65; V. NovotnÝ, Katolická teologická fakulta 1939-1990, s. 53; ABL, Vladimír Kusý, Liber testimonialis de frequentia et progressu in disciplinis theologicis auditoris Domini Vladimiri Kusý (...).

136 Biskupský dekret uložen v ABS, sbírka Správa vyšetřování STB - vyšetřovací spisy (V), arch. č. V-2309 MV, složka V 2309 MV mapa 02, scan 0098-0099. Vicerektorem semináře se stal Jan Veselka, spirituálem Karel Červinkā (1915-1986).

137 Budujeme seminář, Naše spolupráce. Stálá pastorační př́loha Ordinariátního listu litoměřické diecése 10/1948 (nepaginováno, autor neuveden).

138 Ordinariátní list litoměřické diecése 1/1948, 15. 1. 1948, s. 7; ABS, sbírka Správa vyšetřování STB - vyšetřovací spisy (V), arch. č. V-2309 MV, složka V_2309_MV_mapa_02, scan 0070, 0100; Monika Menke, Soudnictví rímskokatolické cirkve v českých zemich v obd̄obi kodifikovaného kanonického práva, Olomouc 2015, s. 224.

139 Ordinariátní list litoměřické diecése 12/1948, 1. 12. 1948, s. 85. ABS, sbírka Správa vyšetřování STB - vyšetřrovací spisy (V), arch. č. V-2309 MV, složka V_2309_MV_mapa_02, scan 0103. Do tohoto úřadu byl však jmenován již také biskupem Weberem 26. 2. 19477; srov. Tam̄éž, složka V_2309_MV_mapa_02, scan 0096. 
k 1. 1. 1949 členem sboru konzultorů ${ }^{140}$ a v dubnu téhož roku také členem sboru spolupracovníků komise pro informační proces svatořečení bl. Zdislavy. ${ }^{141}$ Stal se zkrátka nepostradatelnou a důležitou součástí nového vedení litoměřické diecéze. Jeho činnost však nebyla pouze akademická, o čemž svědčí drobné zachycené stř́ipky v již citovaném diecézním periodiku Naše spolupráce, kde na jaře 1948 uveřejnil 18 okruhů pro májová mariánská kázání, ${ }^{142}$ zároveň pak ve dnech 3.-7. 7. 1948 konal v turnovském klášteře křížových sester exercicie pro ženy. ${ }^{143}$ Ty však absolvoval „oslaben prestálou vážnou chorobou“, ${ }^{144} \mathrm{o}$ níž jinak nevíme nic bližšího.

Mezitím se však zásadním způsobem proměňovala pozice římskokatolické církve ve státě i společnosti, ${ }^{145}$ přičemž ohrožení jejího svobodného působení vnímal především tehdejší československý episkopát, ale také pražská internunciatura, potažmo tedy Svatý stolec. ${ }^{146}$ Pro období př́ípadného ohrožení tak byly církvi v Československu, resp. jednotlivým biskupům a dalším ordinářům, poskytnuty zvláštní instrukce pro její činnost známé obecně jako tzv. mexické fakulty. Význam těchto takřka legendárních dokumentů je v současnosti spíše relativizován, resp. je poukazováno na jejich poměrně malou možnost uplatnění v Československu přelomu 40. a 50. let, a především, že i některé v duchu těchto fakult zřízené struktury byly státními zásahy během několika let (či možná spíše jen měsíců) fakticky rozprášeny. ${ }^{147}$

Ačkoliv ohledně termínu dodání fakult do Československa existuje řada nerožrešených rozporů, ${ }^{148}$ kloníme se spiše $\mathrm{k}$ tomu, že litoměřický biskup Trochta jimi musel disponovat

140 Ordinariátní list litoměřické diecése, 1/1949, 1. 1. 1949, s. 9; ABS, sbírka Správa vyšetřování STB - vyšetřovací spisy (V), arch. č. V-2309 MV, složka V_2309_MV_mapa_02, scan 0101-0102.

141 Ordinariátní list litoměřické diecése 4/1949, 1. 4. 1949, s. 43-44; k této dosud fakticky neznámé diecézní části rané fáze Zdislavina kanonizačního procesu srov. Martin BARus, Kalistovy „Dějiny diecése litoměřické“", Středočeský sborník historický (v tisku).

142 Pastorační náměty, Naše spolupráce. Zpravodaj pro farní spolupráci litoměřické diecése. Stálá pastorační př́loha Ordinariátního listu litoměřické diecése 4/1948 (nepaginováno, autor neuveden).

143 Zprávy, Naše spolupráce. Zpravodaj pro farní spolupráci litoměřické diecése. Stálá pastorační příloha Ordinariátního listu litoměřické diecése 9/1948, 1.9. 1948 (nepaginováno, autor neuveden).

144 Tamtéž. Snad se mohlo jednat o stejné onemocnění, které mu znemožnilo účast na oslavě svátku sv. Tomáše Akvinského v litoměřickém dominikánském klášteře 7. 3. 1949, kde ho zastoupil vicerektor Veselka; $Z$ předpokoje pana biskupa, Naše spolupráce. Zpravodaj pro farní spolupráci litoměřické diecése. Stálá pastorační př́loha Ordinariátního listu litoměřické diecése 4/1949, 1. 4. 1949 (nepaginováno, autor neuveden).

145 Z početné literatury lze obecně odkázat na základní díla Stanislav BALíK - Jiří Hanuš, Katolická církev v Československu 1945-1989, Brno 2013, s. 12-40; Karel KAPLAN, Stát a církev v Československu 1948-1953, Praha Brno 1993; k severočeskému prostředí (tedy k území litoměřické diecéze, které je však poněkud rozsáhlejší) Ivana Hrachová, Perzekuce katolické církve na severu Čech po roce 1948, in: Martina Fiamová - Pavol Jakubčin (edd.), Prenasledovanie cirkví v komunistických štátoch strednej a východnej Európy, Bratislava 2010, s. 473-493.

146 Marek ŠmíD, Apoštolský nuncius v Praze. Významný faktor v československo-vatikánských vztazích v letech 1914-1950, Brno 2015, s. 306-318.

147 Těmito fakultami se v poslední době intenzivně zabývá především Eva Vybíralová; srov. především její dosud nepublikovaná dizertační práce: Eva VyBíRALOVÁ, Untergrundkirche und geheime Weihen. Eine kirchenrechtliche Untersuchung der Situation in der Tschechoslowakei, Disertační práce, Katolická teologická fakulta Univerzity Karlovy, Praha 2017. Fakulty samotné přiblížila v přehledovém (a k jejich významu střízlivě kritickém) článku TÁž, Mimořádné fakulty v Československu v letech 1948-1989, Revue církevního práva 75/2, 2019, s. 43-62. V únoru 2021 se pak této badatelce podařilo v Apoštolském vatikánském archivu objevit originální znění zmíněných fakult, které teprve s naprostou jistotou dokázalo, že se jedná o autentické dokumenty, a nikoliv podvrh StB. TÁž, Mexické fakulty nalezeny! Nebo spíše: konečně potvrzeny ve vatikánském archivu, Zrcadlo církve. Aktuality společnosti pro církevní právo 2/2, 2021, s. 2-3.

148 Tyto komplexně shrnula TÁž, Untergrundkirche und geheime Weihen, s. 91-92. 
nejpozději v polovině roku 1949, snad i poněkud dřive. Do července 1949 (vesměs bez bližšího denního určení) je totiž datováno několik dokumentů, které rozpracovávají mexické fakulty pro potřeby litoměřické diecéze a zároveň v ní zřizují tajnou správní strukturu, která se měla aktivovat $\mathrm{v}$ př́padě zatčení, internace či jiného př́ípadu, kdy by byla omezena jurisdikce diecézního biskupa. ${ }^{149} \mathrm{~V}$ čele této tajné struktury stál tehdejší generální vikář F. Vlček, jeho zástupci (provikáŕi) byli ustanoveni F. Rabas a jeho kolega z bohosloveckého učiliště V. Martinů. Dále bylo v diecézi vytvořeno šest tzv. oblastních vikariátů, tedy zcela nových církevně správních celků, v jejichž čele stáli oblastní vikáři - pro Litoměřicko byl takto určen opět F. Rabas. A své tajné vedení (často se však kryjící s tím stávajícím) získaly také existující okrskové vikariáty. ${ }^{150}$ Kromě toho, že se F. Rabas stal jednou z klíčových postav této tajné struktury, pověřil ho biskup Trochta, ${ }^{151}$ aby ještě vyhotovil směrnice pro jednotlivé vikáře a duchovní správce, které přesně určovaly jejich pravomoci plynoucí z mexických fakult, ${ }^{152}$ což teprve $\mathrm{v}$ praxi umožňovalo jejich reálnou aplikaci. Přestože měly být tyto instrukce předávány tajným vikářům společně s jejich dekrety, ${ }^{153} \mathrm{o}$ jejich naplňování lze spíše pochybovat.

Jedním z důsledků faktické likvidace mužského řeholního života v Československu $(\text { Akce K })^{154} \mathrm{v}$ dubnu 1950 bylo i zásadní ochromení fungování litoměřického bohosloveckého učiliště, kde část profesorského sboru tvořili internovaní řeholníci. ${ }^{155}$ Jaká opatření tehdy F. Rabas jakožto rektor semináře přijal, netušíme. Na jeho prozíravost však nepochybně ukazuje, že přesvědčil biskupa Trochtu, aby studentům pátého ročníku udělil kněžské svěcení již před ukončením studia - tato poloveřejná ordinace se konala 8. 4. 1950 (na Bílou sobotu) v kapli biskupské rezidence. ${ }^{156}$

V této době se již př́islušné státní orgány zabývaly možným zrušením diecézních seminářŭ a vznikem centrálního (státního) semináŕe se sídlem v Praze pro české země a v Bratislavě

149 Tyto dokumenty jsou v četných opisech a výpisech součástí vyšetřovacího svazku skupiny Trochta a spol. (včetně českého překladu). ABS, sbírka Správa vyšetřování STB - vyšetřovací spisy (V), arch. č. V-2309 MV, složka V_2309_MV_podsvazek_2, scan 0020-0037. Jejich edici přinesla rovněž E. VyBíRALovÁ, Untergrundkirche und geheime Weihen, s. 305-315.

150 Strukturu již popsal Jiř́ PlachÝ, Biskup Trochta v hodině velké zkoušky, Securitas Imperii 11, 2005, s. 129-134, s. 132-134. Její přehled a také personální obsazení všech postů (včetně zástupců a sekretářů na všech úrovních) přináší: ABS, sbírka Správa vyšetřování STB - vyšetřovací spisy (V), arch. č. V-2309 MV, složka V_2309_ MV_podsvazek_2, scan 0005-0006.

151 Datace zadání tohoto úkolu je značně nejistá. Dle Rabasových výpovědí spadá bud' do března 1949 (Tamtéž, složka V_2309_MV_podsvazek_3, scan 0100 (výpověd' F. Rabase z 1. 2. 1955), což nám připadá vzhledem k celkové chronologii smysluplnější, případně až do dubna 1950 (Tamtéž, složka V_2309_MV_mapa_02, scan 0059-0060). Tyto výpovědi však nelze brát jako jediná směrodatná datační vodítka.

152 Jejich kompletní znění Tamtéž, složka V_2309_MV_podsvazek_2, scan. 0086-0099.

153 Tamtéž, složka V 2309 MV mapa 02, scan 0060.

154 Jiří Hanuš - Jan STTŘíBRNÝ, Stát a cirkev v roce 1950, Brno 2000, s. 30-31, 50-67.

155 V. NovotnÝ, Katolická teologická fakulta 1939-1990, s. 87. Zároveň byla ochromena (a fakticky zničena) tajná správní struktura litoměřické diecéze, nebot’ mnozí z oblastních i okrskových vikářu byli členy různých rádů a kongregací.

156 Ve své výpovědi F. Rabas uvádí, že se tak stalo „na moje naléháni“; srov. ABS, složka V 2309 MV mapa 02 , scan 0064-0065 (výpověd' F. Rabase z 10. - 12. 11. 1953). Svěcení potvrzují i údaje v v knize svěcenců litoměřické diecéze; srov. ABL, Liber ordinatorum (nepaginováno). Vzájemnou velkou důvěru mezi těmito bohoslovci a biskupem Trochtou ilustrují asi nejlépe životní osudy dvou z nich, Josefa Helikara a Jana Bečváře, kteří zůstali v kontaktu se svým představeným i po odvodu na vojnu (PTP), za což byli později v jednom z politických procesů, který následoval po tom Trochtově, rovněž odsouzeni k dlouholetému vězení; srov. např, Jiří PlachÝ, , Rozpracováni“ “ duchovních litoměrické diecéze Státní bezpečností, Securitas Imperii 11, 2005, s. 5-89, zde s. 25-26, 38-39. 
pro Slovensko. Tamtéž měly působit také jediné dvě bohoslovecké fakulty. Cílem této transformace byla především výchova státu oddanému kléru. ${ }^{157}$ Poté, co se o těchto záměrech dozvěděl F. Rabas, začal připravovat jednak likvidaci litoměřického diecézního semináře, jednak podmínky pro možnost tajného studia stávajících bohoslovců, protože biskupové zpočátku (později se to mělo změnit) odmítali povolit nástup svých alumnů do státního semináře. Přestože valná část dále uvedených informací pochází z vyšetřovacích protokolů vedených jak se samotným Rabasem, tak i s jeho spolupracovníky či studenty, čímž se jejich výpovědní hodnota poněkud snižuje, resp. problematizuje, v základních konturách se jedná o nepochybně $\mathrm{v}$ jádru věrný obraz toho, co se $\mathrm{v}$ litoměřickém semináŕi přibližně od června do srpna 1950 dělo. F. Rabas se snažil zachránit především seminární knihovnu, část jí ukryl na půdě, několik balíků knih - spolu s některými dokumenty ze seminárního archivu (včetně katalogu alumnů) - uschoval za zprostředkování bohoslovců v kryptě pod zvonicí u litoměřického kostela sv. Vojtěcha, který se nachází nedaleko bývalého semináře, 158 část si mohli odnést bohoslovci, 159 část včlenil F. Rabas do své soukromé bibliotéky 160 a zbytek měl údajně skončit ve stoupě. ${ }^{161}$ „Téměr celý archiv seminární a velkou část archivu manželského" (tj. zřejmě agendu diecézního soudu, která mu byla přidělena jakožto obhájci manželského svazku) pak Rabas v červnu $1950 \mathrm{z}$ bezpečnostních důvodů ve svém seminárním bytě spálil. ${ }^{162}$ Bohoslovci si rovněž rozebrali různé hudebniny a hudební nástroje a sestra Moderanda, která se starala o seminární kuchyn̆, rozdala zbylé potraviny potřebným. ${ }^{163}$ Pro možné využití v budoucím tajném semináři odnesl jeden $\mathrm{z}$ bohoslovců také dva cyklostyly, na nichž měl množit přednášky, skripta a další materiály, které mu F. Rabas poskytnul. ${ }^{164}$

Rektor Rabas svým studentům s vědomím biskupa Trochty zakázal, aby nastoupili do tzv. státního semináře v pražských Dejvicích, protože ten „bude zř́zen bez dohody s čsl. episkopátem“, přičemž v př́ípadě, že se biskupové rozhodnou tam studium povolit, měl

${ }^{157} \mathrm{~K}$ tomuto podrobně i s vypsáním všech kanonických problémů V. NovotNÝ, Katolická teologická fakulta 1939-1990, s. 93-143.

${ }^{158}$ ABS, sbírka Správa vyšetřování STB - vyšetřovací spisy (V), arch. č. V-2309 MV, složka V_2309_MV_ mapa_02, scan 0088-0090 (výpověd' F. Rabase z 16. 11. 1953). Jednalo se o značně obskurní úkryt, nebot' knihy byly v bednách a balících uloženy pod vrstvou kostí, jak dosvědčují nejen citované výpovědi, ale také fotografie přiložené ke spisu - tamtéž, složka V_2309_MV_obálka 1_C.

159 Tamtéž, složka V_2309_MV_mapa_02, scan 0089 (výpověd' F. Rabase z 16. 11. 1953).

160 Při prohlídce Rabasova pokoje na cvikovské faře v záŕí 1954 (asi rok a půl po jeho zatčení - srov. níže) byla nalezena také jeho knihovna o více jak tisíci svazcích, ,z nichž značné procento nese razítko litoměřického semináře“; srov. ABL, Biskupská konzistoř 1941-1990, sign. III-A-1 - personália, František Rabas. V širších souvislostech Martin Barus, Farni knihovna Cvikov. Katalog, Litoměřice 2019 (nepublikovaný rukopis), s. 7-8. Ten je dostupný i online <https://www.dltm.cz/file/122978/cvikov-katalog-fk-komplet.pdf> [cit. 4. 8. 2021].

161 Tento údaj přináší unikátní strojopisný text Kardinál Štěpán Trochta a jeho diecéze v $r$. 1950, jehož autorem byl zřejmě sám F. Rabas (byt' je v textu uváděn ve třetí osobě, př́ípadně byl sepsán na základě od něj získaných informací); ABL, Josef Rabas, sign. LP-10/2, Kardinál Stépán Trochta a jeho diecéze v r. 1950, s. 1. Toto sdělení lze spíše rozporovat, nebot’ fond litoměřické seminární knihovny uložený v Knihovně Biskupství litoměřického je poměrně obsáhlý. Zároveň je však pravdou, že především knihy z první poloviny 20. století v něm ve značné míře překvapivě absentují, a tak ztrátu části fondu nelze zcela vyloučit.

162 ABS, sbírka Správa vyšetřování STB - vyšetřovací spisy (V), arch. č. V-2309 MV, složka V_2309_MV mapa_02, scan 0063 -0064 (výpověd’ F. Rabase z 10.-12. 11. 1953). Jedná se zároveň o jednu z mála zmínek, že $\mathrm{v}$ době, kdy byl rektorem semináře, bydlel (dle předpisů) v jeho budově a nikoliv se svou matkou v domě na Dómském náměstí č. 2. Tato zde žila ještě v roce 1954, její další osudy jsou neznámé.

163 Tamtéž, složka V_2309_MV_mapa_02, scan 0089.

164 Tamtéž, složka V_2309_MV_mapa_02, scan 0108, 0111 (výpověd' F. Rabase z 12. 7. 1954). 
bohoslovce o této změně informovat. ${ }^{165}$ Svůj odpor k budoucímu centrálnímu semináŕi a fakultě dal veřejně najevo také při dvoutýdenním politickém školení, kterého se měli na přelomu června a července 1950 ve Veltrusech zúčastnit všichni profesoři bohosloveckých fakult a učilišst' a při němž sledoval přednášky „, výrazem nepokrytého odporu“ “ 166 Přesto ještě $\mathrm{v}$ záŕí téhož roku uvažoval o svém možném nástupu do státního semináře $\mathrm{v}$ Dejvicích (není však zřejmé na jakou pozici), v čemž mu dal - tehdy již internovaný - biskup Trochta plnou moc vázanou na souhlas episkopátu s existencí fakulty. ${ }^{167}$

Pokud měl F. Rabas v tomto ohledu nějaké dilema, bylo vyřešeno za něj, nebot' k 1. 9. 1950 byl jmenován administrátorem v Horním Litvínově, odkud spravoval také farnosti Český Jiřetín, Fláje, Klíny, Mikulov a Moldava. ${ }^{168}$ Odcházel tam však již ve zcela jiné pozici. Dne 19. 7. 1950 byl ve své rezidenci internován biskup Š. Trochta, ${ }^{169}$ čímž měly být uplatněny směrnice vydané $\mathrm{v}$ červenci předchozího roku, kdy se do čela tajné struktury diecéze měli postavit $\mathrm{F}$. Vlček a F. Rabas. ${ }^{170}$ Ostatně sám Vlček se rovněž v záŕí nepochybně pod tlakem státních úřadů musel vzdát úřadu generálního vikáře a stal se administrátorem v Rovensku pod Troskami. ${ }^{171}$ Nový litvínovský administrátor tuto tajnou funkci zrémmě opravdu začal vykonávat, a to především - pokud je známo - ve vztahu k internovaným řeholnicím, jimž uděloval pokyny $\mathrm{k}$ tzv. věčným slibům a dále př́pravou bohoslovců na

165 Tamtéž, složka V_2309_MV_mapa_02, scan 0082-0083 (výpověd’ F. Rabase z 15. 11. 1953); Kardinál Štěpán Trochta a jeho diecéze $\bar{v}$ r. 1950, s. $\overline{1}-2$.

166 V. NovotnÝ, Katolická teologická fakulta 1939-1990, s. 102.

${ }^{167}$ ABS, sbírka Správa vyšetřování STB - vyšetřovací spisy (V), arch. č. V-2309 MV, složka V_2309_MV_obálka 1_C, scan. 0098. Tyto informace sdělil Rabas i při svém výslechu, tamtéž, složka V_2309_MV_mapa_02, scan. $0 \overline{0} 65$ (výpověd' F. Rabase z 10.-12. 11. 1953). Informační spojení internovaného biskupa a jeho spolupracovníků obstarával dle známých (a Státní bezpečností odhalených) informací především sekretár F. Krutílek. Citovaný text založený na Rabasových vzpomínkách však dokládá, že jednou ze „spojek“ byla i matka F. Rabase, která bydlela $\mathrm{v}$ domě sousedícím s biskupskou zahradou (,Ona to byla, která umožnila přes nejpř́snější dozor setkání obou, rektora a biskupa, v důležité otázce zřízení generálního semináře."); Kardinál Śtěpán Trochta a jeho diecéze v $r .1950$, s. 2. Trochta ani Rabas však tuto starou ženu při svých výsleších neprozradili.

168 Dekret nedohledán v žádné z příslušných farních složek (ABL, Biskupská konzistoř 1941-1990, sign. II-A-1 beneficia) ani osobní složce Františka Rabase (ABL, Biskupská konzistoř 1941-1990, sign. III-A-1 - personália) v ABL. Spravovaný farní obvod po Rabasovi ve stejném rozsahu na počátku roku 1951 převzal Oldřich Vinduška (1918-2007) (ABL, Biskupská konzistoř 1941-1990, sign. II-A-1 - beneficia, Litvínov), odchod Rabase z Litoměřic na počátku záŕí 1950 potvrzuje Kardinál Štěpán Trochta a jeho diecéze v $r .1950$, s. 1.

${ }^{169}$ Ivana Hrachové, Internace biskupa Štěpána Trochty, in: Jan Mervart - Veronika Střed’ová (edd.), České, slovenské a československé dějiny 20. století 4, Ústí nad Orlicí 2009, s. 91-99, zde s. 92-93.

170 Celá tajná struktura byla ustanovena tím způsobem, že v př́padě, kdy je jakýmkoliv způsobem omezena jurisdikce biskupa „ř́ídí diecesi současně dva generální vikáři, tj. současný generální vikář s prvním generálním provikářem a pak další a dalši “, přičemž první z nich vždy disponuje fakultami určenými pro biskupa, druhý pro generálního vikáře. $V$ prvním př́ípadě to tedy byli Vlček $s$ Rabasem, dále př́ípadně jeden $z$ nich společně $\mathrm{s}$ druhým provikářem V. Martinů. Každý z provikářù si měl zároveň určit tř̌i své zástupce, na něž uvedené pravomoci měly přejít; srov. ABS, sbírka Správa vyšetřování STB - vyšetřovací spisy (V), arch. č. V-2309 MV, složka V 2309_MV_podsvazek_2, scan. 0043-0044. Nakolik lze však důvěřovat následující Rabasově výpovědi, je dosti sporné: „,V den internace biskupa Trochty koncem července nebo počátkem srpna 1950 přišel za mnou do semináře kuchař a zř́zenec biskupské domácnosti Lád’a a přinesl mně biskupův vzkaz, slovy, Vše co má biskup vám dává‘, což jsem chápal v tom smyslu, že biskup doplnil a rozšíríil moji pravomoc tajného generálního vikáře, jako např. ustanovení zpovědníkủ pro řeholnice, připustit $\mathrm{k}$ svěcení bohoslovce, včlenění cizích kněží do svazku litoměřické diecése, a jiné, kteréžto úkoly normální generální vikář vykonat nemůže. Tímto biskupovým vzkazem jsem se stal tajným generálním vikářem s rozšířenou pravomocí, takže jsem mohl rozhodovat i o takových záležitostech, které náležely jen biskupovi, čímž jsem se stal jakýmsi illegálním zástupcem biskupa“. Pokud bylo Rabasovi známo, Vlček ani Martinů podobný vzkaz nedostali; srov. tamtéž, složka V_2309_MV_mapa_02, scan 0062 (výpověd’ F. Rabase z 10. - 12. 11. 1953).

171 ABL, Biskupská konzistoř 1941-1990, sign. II-A-1 - beneficia, Týn-Rovensko pod Troskami. 
přijetí kněžského svěcení, k čemuž jim nakonec zajistil tajného biskupa Ladislava Hlada (1908-1979). ${ }^{172}$ Jak dlouho však v této tajné funkci působil, není zřejmé, nebot' 8. 12.1950 byl Trochta nucen jmenovat novým generálním vikářem nechvalně proslulého Eduarda Olivu (1905-1972), ${ }^{173}$ který patřil mezi tzv. vlastenecké kněze. V návaznosti na to pak přibližně v dubnu 1951 doručil bývalý Trochti̊v sekretář František Krutílek (1911-1996) Rabasovi biskupi̊v dopis, v němž mu nařizuje, aby E. Olivu pokládal za řádně ustanoveného generálního vikáře, a to do té doby „,dokud by svým jednáním nepřišel do rozporu s církevním právem a tím upadl do exkomunikace“ - v takovém př́padě měla být opět diecéze rrízena dle předchozích tajných směrnic. ${ }^{174}$ Nakolik lze tedy od tohoto data považovat Rabase za již bývalého tajného generálního vikáře, resp. zda se pak de iure této funkce ještě někdy (alespoň z vlastního přesvědčení) ujal, je otázkou (nadto asi př́liš nerozřešitelnou) spíše pro odborníky na církevní právo. Známé exkomunikační dekrety z roku 1949, 175 z nichž mj. plynula samočinná exkomunikace členů komunistických stran a podporovatelů komunistických režimů, lze totiž dle našeho mínění plně vztáhnout i na E. Olivu, nehledě na některé další skutečnosti plynoucí z Olivova dalšího působení. Vzhledem $\mathrm{k}$ tomu, že Rabas následně v roce 1951 či 1952 vyhledal tři další kněze, aby se stali jeho tajnými zástupci a že jeden tuto funkci alespoň částečně vykonával, můžeme spíše usuzovat, že se jako tajný generální vikáŕ skutečně choval. ${ }^{176}$

O možných interpretacích Trochtova dopisu mohl F. Rabas přemýšlet již na faře ve Cvikově na Českolipsku, kam byl přeložen 23. 2. 1951, nebot' - jak píše E. Oliva v dopisu přiloženém ke jmenovacímu dekretu - ,jste vyslovil prání a ochotu působiti v duchovní

172 ABS, sbírka Správa vyšetřování STB - vyšetřovací spisy (V), arch. č. V-2309 MV, složka V_2309_MV_ mapa_02, scan. 0062, 0065 a 0067 (výpověd’ F. Rabase z 10. - 12. 11. 1953). Jednalo se o vyšěcení Jana Heriána (1911-1978) a Františka Vítka (1923-1993), k němuž došlo 11. 12. 1952 v Kladně-Rozdělově.

173 I. HrachovÁ, Internace biskupa Štěpána Trochty, s. 94-96.

174 ABS, sbírka Správa vyšetřování STB - vyšetřovací spisy (V), arch. č. V-2309 MV, složka V_2309_MV mapa_02, scan. 0095 (výpověd' F. Rabase z 16. 12. 1953). Originál (nedatovaný dopis s incipitem „Ve jénénu Otce i Syna i Ducha sv. - amen“) tamtéž, složka V 2309 MV podsvazek 2, scan. 0107-0110. O tomto dopisu - ovšem bez uvedení podrobností týkajících se exkomunikace - informoval Š. Trochta také přednostu Státního úřadu pro věci církevní Jana Dolka; srov. Josef HurT, Litoméřický biskup Štěpán Trochta a osudy jeho spolupracovníků v agenturním rozpracování StB, in: Markéta Doležalová (ed.), Církev za totality - lidé a místa. Sborník k životnímu jubileu opata Heřmana Josefa Tyla, Praha 2016, s. 27-45, zde s. 32-33.

${ }^{175}$ K nim Adolf RÁzeK, Exkomunikačni dekrety, Securitas Imperii 11, 2005, s. 135-194; S. BaLíK - J. Hanuš, Katolická cirkev v Československu 1945-1989, s. 24-26.

${ }^{176}$ F. Rabas nejprve v tomto ohledu mlžil a uváděl, že se mělo jednat o tzv. vlasteneckého kněze Jana Vraštila (1891-1955) z Liberce a jménem mu již neznámé administrátory z Mladé Boleslavi a Rumburka, které si vytipoval na podzim 1952, ale už s nimi kvůli zatčení nestihl celou věc projednat. ABS, sbírka Správa vyšetřování STB - vyšetřovací spisy (V), arch. č. V-2309 MV, složka V_2309_MV_mapa_02, scan. 0061-0062 (výpověd' F. Rabase z 10. - 12. 11. 1953). Posléze však přiznal, že oslovil rumburského ā̄ministrátora Jaroslava Dostálka (1909-1996) (ten byl však v této funkci jen od 20. 2. do 30. 4. 1951, což však výmluvně koresponduje s datací, kdy obdržel od Krutílka zmíněný Trochtův dopis), dále administrátora v Kravařích a někdejšího rektora litoměřického semináře z roku 1946/1947, V. Hataše, a svého někdejšího studenta Josefa Hádka (1922-2009), administrátora v Holešicích u Mostu (tamtéž, složka V_2309_MV_mapa_02, scan. 0070-0071). J. Dostálek, který na rozdíl od ostatních nebyl zatčen a stal se administrátorem v Bělé pod Bezdězem, tuto tajnou funkci (alespoň v omezené míře) skutečně vykonával, když zprostředkoval kněžská svěcení některých dalších litoměřických bohoslovců, např. Jaroslava Vyterny (1927-2019) a Josefa Knödla (1929-1993) biskupem L. Hladem. E. VyBíralová, Untergrundkirche und geheime Weihen, s. 79; Miloslava KAHounovÁ, Život a odkaz biskupa Ladislava Hlada, Diplomová práce, Katolická teologická fakulta Univerzity Karlovy, Praha 2001, s. 25-26. Této své tajné funkce se pak vzdal až v květnu 1958 ve svém dopisu adresovaném ministerstvu vnitra, což také vypověděl při výslechu v rámci Hladova procesu. E. VyBíralovÁ, Untergrundkirche und geheime Weihen, s. 113 , pozn. 306 . 
správě v místě, kde by Vás působnost pro zdravotní stav nevyčerpávala“. 177 Od 1. 4. téhož roku také ještě spravoval okolní farnosti Mařenice, Krompach a Kunratice. ${ }^{178} \mathrm{Z}$ doby cvikovského působení se dochovalo torzo Rabasovy intenční knihy psané na rubu různých formulářủ a zahrnující období od podzimu 1951 do února následujícího roku, přičemž jako zajímavé se mohou jevit kromě zmínek o některých pohřbech a svatbách marginální přípisky evidující drobná vydání za různé cesty po okolí (do Nového Boru, Krompachu, České Lípy a Liberce) či předměty denní potřeby (,oprava vařiče „,nové kalhoty“, „,ávodní kuchyně", „pivo“, „uzeniny“, „chléb“, „dřivi“"). ${ }^{179}$

Ačkoliv za cvikovského působení nebyl zřejmě ve své tajné činnosti př́liš aktivní, byt' ve vyšetřovacích spisech jsou zmínky, že i tehdy se scházel např. s bývalým Trochtovým sekretářem F. Krutílkem, jemuž předával různé informace, F. Vlčkem, V. Martinů či některými bohoslovci, s nimiž si i korespondoval, pozornosti bezpečnostních orgánů neušel. Zejména v důsledku výsledků vyšetřování skupin Krutílek a spol. a Mádr a spol. byly odhaleny kontakty vedoucí $\mathrm{k}$ biskupu Trochtovi a systém předávání zpráv určených zejména pro Svatý stolec. Na základě rozkazu č. 422, který vydala dne 16. 1. 1953 Krajská správa státní bezpečnosti Liberec, byl Rabas ještě téhož dne večer zatčen. ${ }^{180}$ Následně byl držen ve vazbě v liberecké věznici, kde byly také pořizeny jeho již protokolované výslechy - první 31. 10. 1953, další pak zejména v listopadu a prosinci téhož roku a několik doplňkových pak ještě v období od dubna do července následujícího roku. ${ }^{181}$

Stejného dne jako Rabas byli zatčeni také Š. Trochta, F. Vlček a Bohumil Landsmann (1916-1984), rovněž Trochtův důvěrník zapojený na podřadné pozici (2. sekretář okrskového vikariátu Litoměřice) do tajné správní struktury litoměřické diecéze a v době zatčení administrátor v Býčkovicích u Litoměřic a okolních farnostech. ${ }^{182}$ Tito čtyři kněží byli následně zařazeni do procesu nazvaného Trochta a spol. Písemné materiály dokumentující vyšetřování jejich případu představují velmi podrobný, byt' jistě svou povahou zkreslený pohled na situaci litoměřické diecéze na přelomu 40. a 50. let 20. století. Jak již konstatovali mnozí, ${ }^{183}$ pochopení všech popisovaných vazeb a souvislostí i v návaznosti na jiné procesy, zejména Krutílek a spol., vyšetřování biskupa L. Hlada a kněží Josefa Helikara (1923-2000), Jana Bečváře (1924-2005) či Vojtěcha Kodery (1914-2006), si žádá zvláštní

177 ABL, Biskupská konzistoř 1941-1990, II-A-1 - beneficia, Cvikov; originál dekretu srov. ABS, sbírka Správa vyšetřování STB - vyšetřovací spisy (V), arch. č. V-2309 MV, složka V_2309_MV_mapa_02, scan 0076.

178 Tamtéž.

179 ABL, František Rabas (nezpracováno). Tento fond představuje samozřejmě pouhé nepatrné torzo Rabasovy pozůstalosti, která byla nalezena při katalogizaci cvikovské farní knihovny (srov. Martin Barus, Farní knihovna Cvikov. Katalog, Litoměřice 2019, s. 9 [https://www.dltm.cz/file/122978/cvikov-katalog-fk-komplet.pdf]). Klíčové dokumenty, zejména jmenovací dekrety, byly zabaveny a staly se součástí vyšetřovacího spisu (ABS, sbírka Správa vyšetřování STB - vyšetřovací spisy (V), arch. č. V-2309 MV, složka V_2309_MV_obalka_2), zbytek byl zřejmě zlikvidován.

180 ABS, sbírka Správa vyšetřování STB - vyšetřovací spisy (V), arch. č. V-2309 MV, složka V_2309_MV mapa_02, scan. 0007. Litoměřickou konzistoř o této události informoval na základě sdělení katechetky Žejdlíkové ze Cvikova dopisem z 19. 1. 1953 okrskový vikář v Novém Boru František Mai (1885-1956). ABL, Biskupská konzistoř 1941-1990, II-A-1 - beneficia, Cvikov.

181 ABS, sbírka Správa vyšetřování STB - vyšetřovací spisy (V), arch. č. V-2309 MV, složka V_2309_MV _ mapa_02, passim.

182 Spolu s nimi byl zatčen také J. Kuška, který však po několika dnech pobytu v liberecké vazební věznici zemřel; srov. souhrnně Michal PEHR a kolektiv, Cestami křest'anské politiky. Biografický slovník k dějinám křest'anských stran v českých zemích, Praha 2007, s. 151.

183 Naposledy J. HuRT, Litoměrický biskup Štěpán Trochta, s. 37. 
pozornost věnovanou pouze tomuto prŕípadu. ${ }^{184}$ Klíčové události, k nimž se - nepochybně pod značným nátlakem ${ }^{185}$ - F. Rabas přiznal a které považujeme dnes při jeho životopisné rekapitulaci za nosné, byly zmíněny již výše. Přesto zřejmě není nesmyslné dát zde prostor také dílčímu rozsudku vynesenému nad F. Rabasem, který je součástí celkového rozsudku nad celou skupinou: ${ }^{186}$ „Obviněný Rabas je vyškolený agent vatikánské špionážní služby. Po únoru 1948 se zúčastňoval tajných schĩzek u obviněného Trochty, kde se jednalo o stanovení postupu pri provádèní nepřátelské činnosti, zejména se zaměřil proti státnímu úr̆adu pro věci církevní. Obviněný Rabas utvrzoval kněze a bohoslovce v nepřátelském postoji vưči státnímu zř́zení a zúčastňoval [se] i vytvářeni sitě tajných vikářu v litoměrické diecesi. Rozpracoval tajné fakulty pro jednotlivé kněžské kategorie a byl jmenován obviněným Trochtou tajným generálním vikářem, $k$ čemuž složil tajnou přisahu. Obviněný Rabas dále organisoval tajný seminář bohoslovců a nabádal bohoslovce, aby nevstupovali do státního semináre. Mimo to obviněný Rabas uschoval nebo dal uschovat mnoho cenných predmětů, které pocházely z litoměrické diecese. Obviněný Rabas dále konal četné cesty, při kterých shromažd'oval zprávy různého druhu, z nichž některé tvořily obsah státního tajemství, a předával je obviněnému Trochtovi, ač věděl, že tyto jsou odesílány do Vatikánu. Obviněný Rabas k této činnosti se v podstatě doznal, hájil se však tím, že nevěděl, že obviněný Trochta ony zprávy, které obviněný Rabas Trochtovi predával, posilá do Vatikánu. Tato jeho obhajoba je však vyvrácena výpovědí svědka Krutilka, kterému soud neměl důvod nevěrit, podle níž obviněný Rabas poznal z hlášení vatikánského rozhlasu, že existuje spojení mezi litoměrickou diecesí a Vatikánem. Obviněný Rabas také jako dlouholetý agent Vatikánu a církevni hodnostár̆ byl si jasně vědom toho, že biskupové dodávají zprávy do Vatikánu, a tudiž věděl, že zprávy jím dané obviněnému Trochtovi jdou do Vatikánu. Jestliže presto tyto zprávy i nadále předával, lze usoudit, že i pro ten připad byl s dodáváním zpráv do Vatikánu srozuměn, což také vyplývá z jeho neprátelského postoje k našemu státnímu zř́zeni." "187 Senát Nejvyššího soudu v Praze svým rozsudkem ze dne 23. 7. 1954 shledal všechny obviněné vinnými z velezrady a Trochtu, Rabase a Landsmanna navíc z vyzvědačství a odsoudil je k trestu odnětí svobody, konkrétně u Trochty na 25 let, Rabase na 20 let, Vlčka na 15 let a Landsmanna na 7 let. ${ }^{188}$

Jaká všechna vězení F. Rabas prošel, není přesně známo. Na přelomu ledna a února 1955 byl vyslýchán a umístěn ve věznici v Ústí nad Labem, což bylo však zřejmě pouze dočasné řešení. ${ }^{189}$ V rámci žádosti o náhradu škody za dobu odnětí svobody (viz níže) totiž zmiňuje, že také pracoval v uranových dolech. Lze tedy předpokládat jeho pozdější zařazení do tzv. kněžských oddělení některých ze smutně proslulých věznic v oblasti Jáchymova, Horního

184 Jeho shrnutí je však v jádru známo; srov. zejména J. HuRT, Litoměřický biskup Štěpán Trochta, s. 37; J. PlachÝ, Biskup Trochta v hodině velké zkoušky, s. 133-134. Edici klíčových pasáží Trochtových výpovědí pak přináší Jaroslav Novosad, Štěpán Trochta. Svědek ,, T“, Praha 2001, s. 129-143.

$185 \mathrm{~V}$ prvních měsících vazby všech čtyřech obviněných nebyly výslechy protokolovány a obvinění popírali jakoukoliv vinu; srov. zprošt’ující rozsudek Nejvyššího soudu uložený v ABS, sbírka Správa vyšetřování STB - vyšetřovací spisy (V), arch. č. V-2309 MV, složka V_2309_MV_mapa_01, scan. 0087-0088.

186 Tamtéž, složka V_2309_MV_mapa_01, scan. 0058-0066. Klíčové pasáže rozsūdku nad celou skupinou přináší J. Novosad, Štěpán Tročchta, s. 145-147.

187 ABS, sbírka Správa vyšetřování STB - vyšetřovací spisy (V), arch. č. V-2309 MV, složka V_2309_MV_ mapa 01, scan. 0061-0062.

188 Tamtéž, složka V_2309_MV_mapa_01, scan. 0065-0066.

189 Tamtéž, složka V_2309_MV_podsvazek_3, scan 0106 (výpověd' Františka Rabase 28. 1. 1955); tamtéž, složka V_2309_MV_podsvazek_ 3, scan 0088 (výpověd' Františka Rabase 1. 2. 1955). 
Slavkova či Př́brami. Po květnové amnestii roku 1960 byla již většina duchovních soustředěna ve Valdicích, kam byl umístěn také František Rabas. ${ }^{190}$

Zatímco na základě zmíněné amnestie byli na jaře 1960 propuštěni Š. Trochta, 191 F. Vlček ${ }^{192}$ a nejpozději tehdy také B. Landsmann, ${ }^{193} \mathrm{~F}$. Rabas zůstal stále ve vězení. Na svobodu se dostal až 21.5. 1964, tedy po 11 letech, 4 měsících a 5 dnech od zatčení. ${ }^{194}$ Vzápětí však byl, jako řada dalších duchovních, povinně umístěn do charitního domova v Senohrabech u Benešova, který byl určen pro přestárlé či nemocné kněze. Detaily z této etapy Rabasova života také neznáme. ${ }^{195}$ Vzhledem $\mathrm{k}$ výše popsanému blízkému vztahu F. Rabase se Š. Trochtou je poněkud překvapivé, že v písemné pozůstalosti litoměřického biskupa ${ }^{196}$ naprosto absentují dopisy, které by mu tento jeho bývalý tajný generální vikář zasílal právě ze Senohrab, přičemž se již jednalo o dobu, kdy jim ve vzájemné korespondenci (a fakticky i v osobních stycích) nemohlo být bráněno. Nakolik se jedná o doklad zhoršení vzájemných vztahů či jen nedochování pramenů (v uvedené pozůstalosti se nachází četná korespondence z období Trochtovy internace v 60. letech 20. století), nejsme schopni sdělit.

V souvislosti s událostmi pražského jara se objevila možnost, že by se fakticky v internaci v jihočeském Radvanově žijící Š. Trochta mohl opět ujmout úřadu litoměřického biskupa. Vzhledem k tomu, že jako jediný sídelní biskup z českých zemí byl v 50. letech pravomocně odsouzen, musel být před návratem do Litoměřic rehabilitován, $\mathrm{k}$ čemuž dal podnět rozsudek Nejvyššího soudu z 19. 7. 1968, který zrušil předchozí odsuzující rozsudek z 23. 7. 1954. ${ }^{197}$ Př́pad Trochta a spol. tedy znovu projednala Krajská prokuratura v Ústí nad Labem, která svým usnesením z 22. 11. 1968 zcela zastavila stíhání všech v případu obviněných osob. ${ }^{198}$

Na základě tohoto rozhodnutí se F. Rabas prostřednictvím advokáta Karla Čermáka, který zřejmě zastupoval všechny společně obviněné, ${ }^{199}$ rozhodl dopisem datovaným v Praze

190 P. MatĚJKA, Literárně činni členové, s. 247. F. Rabase jako svého spoluvězně ve Valdicích několikrát zmiňuje ve své vězeňské korespondenci mj. Ján Chryzostom Korec, SJ (1924-2015), který se po roce 1989 stal nitranským biskupem. Ján Chryzostom Korec, Od barbarskej noci. Listy z väzenia, Bratislava 2004, passim. V obecnější rovině Jan SYNEK, Svobodni v nesvobodě. Náboženskýživot ve věznicích v obdobi komunistického režimu, Praha 2013; TÝž, Kněžská oddělení v československých věznicích a život v nich, in: M. Doležalová (ed.), Církev za totality, s. 94-108.

191 Složitým okolnostem tohoto propuštění se věnují např. J. HuRT, Litoměřický biskup Štěpán Trochta, s. 38-41; J. Novosad, Štěpán Trochta, s. 157-177.

192 J. HurT, Litoměrický biskup Štěpán Trochta, s. 41.

193 Datum jeho propuštění se nepodařilo přesně zjistit. V žádných personálních dokladech uložených v ABL není délka jeho věznění ani následné civilní povolání před opětným nástupem do duchovní správy v roce 1969 uvedena. Propuštění nejpozději v roce 1960 lze obhájit i s ohledem na jeho sedmiletý trest.

194 ABL, Josef Rabas, sign CH-21, Žádost F. Rabase Ministerstvu spravedlnosti o náhradu škod za období odnětí svobody z 18. 7. 1969.

195 Ostatně pozornost věnovaná takovýmto charitním zařízením a životu v nich je zatím pouze spíše okrajová.

196 ABL, Trochtiana, passim.

197 ABS, sbírka Správa vyšetřování STB - vyšetřovací spisy (V), arch. č. V-2309 MV, složka V_2309_MV mapa_01, scan. 0074-0113. Za pozornost stojí především obsáhlé odůvodnění tohoto rozhodnutí. Na základě tohoto rozhodnutí se mohl Trochta ujmout správy litoměřické diecéze k 1. 9. 1968.

198 Tento dokument je citován v žádosti F. Rabase Ministerstvu spravedlnosti o náhradu škod za období odnětí svobody z 18. 7. 1969 (ABL, Josef Rabas, sign CH-21). V archivním fondu ústecké krajské prokuratury se však tento rehabilitační dokument nenachází, nebot' býval obvykle zasílán soudu, který vynesl původní rozsudek v tomto př́padě tedy Nejvyššímu soudu v Praze. Za snahu o dohledání tohoto dokumentu a laskavé objasnění dobových procesů děkujeme Mgr. Sabině Duškové ze Státního oblastního archivu v Litoměřicích.

199 Jakožto obhájce Š. Trochty jej uvádí J. Novosad, Štěpán Trochta, s. 132. 
18. 7. 1969 žádat Ministerstvo spravedlnosti o náhradu škody za své uvěznění. Náhrada se měla týkat ztráty výdělku, škod způsobených na zdraví „výkonem trestu a zejména prací $v$ dolech na uran“", zabaveného osobního nábytku, zabavené odborné knihovny, motorky ČZ 250 a hotovosti. Celkově pak činila 248720 Kčs, přičemž F. Rabas ještě uvedl, že vazbou a vězením byl rovněž poškozen na výši vyměřované penze. ${ }^{200}$ Ministerstvo si k celé záležitosti od F. Rabase vyžádalo ještě další dokumenty týkající se jeho výkonu trestu, což mu dopisem z 6. 10. 1969 sdělovala dr. Marečková zastupující advokáta Čermáka. ${ }^{201}$

Zda Rabas potřebné dokumenty obstaral, netušíme. Přibližně ve druhé polovině ř́ijna totiž odjel do Mnichova, kde mu bylo státními orgány dovoleno navštívit bratra Josefa. ${ }^{202}$ A právě v Mnichově F. Rabas v podvečer 30. 10. 1969 zemřel. ${ }^{203}$ Pohřben byl následně 3. 11. téhož roku v Rottendorfu u Würzburgu, kde tehdy bydlel jeho bratr Josef. ${ }^{204}$ Biskupa Š. Trochtu o úmrtí jeho věrného spolupracovníka informoval (tajný) biskup pražské arcidiecéze Kajetán Matoušek (1910-1994) dopisem z 3. 11. 1969, jemuž tuto zprávu týž den telefonicky sdělil J. Rabas. ${ }^{205}$

Závěrem lze uvést, že F. Rabas se během svého života musel vyrovnat hned s několika krizemi, které zasáhly českou římskokatolickou církev ve 20. století. První z nich byla ta, do níž se již od konce 19. století dostala většina tradičních mužských řeholních řádů. Sekularizační a další vlivy, které ji způsobily, se přirozeně promítly i do sktruktur světského duchovenstva, kde se zásadně začal projevovat nedostatek kněžských povolání, v českém prostředí prohloubený ještě po roce 1918. V těchto souvislostech se rodina z okresního města, jejíž oba mužští potomci si zvolili duchovní cestu, nejeví jako zcela běžná. F. Rabas však této krizi čelil nejen osobním př́kladem, ale také dlouhodobým úspěšným působením v serafinských školách, které v kapucínském prostředí představovaly relativně úspěšné řešení nedostatku řádového dorostu. Nakolik je pak Rabasův odchod z řeholního společenství výsledkem jeho podvolení se této krizi, kdy už ani on jí nebyl schopen déle vzdorovat, nebo měl jiné příčiny, nelze rozhodnout.

Druhou takovouto krizi, ještě mnohem závažnější, protože se nejednalo o problém pouze církevní, představuje odsun německého obyvatelstva po druhé světové válce. ${ }^{206}$ Také zde je Rabasova rodina zasažena zcela prŕmo a její osud pregnantně dokazuje, jak tenká linie

${ }^{200}$ ABL, Josef Rabas, sign CH-21, Žádost F. Rabase Ministerstvu spravedlnosti o náhradu škod za období odnětí svobody z 18. 7. 1969.

201 Tamtéž.

202 Toto konstatování vyplývá mj. ze zprávy o Rabasově úmrtí v diecézním oběžníku; srov. Oběžník [litoměřické diecéze] 14/1969, 12. 11. 1969, s. [1].

203 Stalo se tak v dodnes fungující nemocnici Klinikums rechts der Isar der Technischen Hochschule v Ismaninger Straße 22; ABL, Josef Rabas, sign CH-21, Potvrzení o úmrtí Františka Rabase vydané Standesamt München 31. 10. 1969.

204 Diecézní oběžník, který rovněž přinesl zprávu o jeho úmrtí, uvádí pouze ,pochován 3. 11. v Německu“; srov. Oběžník [litoměřické diecéze] 14/1969, s. [1]; dobový článek v Katolických novinách uvádí jako místo pohřbu Mnichov (Ze světa, Katolické noviny 21, 1969, č. 48, 30. 11. 1969, s. 3). Správné místo pohřbu uvedeno in: P. MATĚJKA, Literárně činní členové, s. 247. Na stejném místě byl pak v roce 2003 pohřben i J. Rabas.

${ }^{205}$ ABL, Trochtiana, kart. č. 5, sign. 5/90. Z tohoto dopisu zřejmě pochází i výše citovaná informace o místu pohřbu, nebot' Matoušek píše ,pohřeb měl dnes 3. 11.v D. B. R.“. Kvůli svému pobytu na biskupské synodě v Římě si však (podle uvedeného prezentátu) biskup Trochta tento dopis přečetl až 26. 11., přičemž tato proluka se následně projevila i na dataci výše citované zprávy o Rabasově úmrtí v Katolických novinách.

206 Z pohledu německých katolických duchovních na př́kladu litoměřické diecéze viz Zlatuše KuKÁNOvÁ, ,,Rád bych byl sloužil déle. "K odsunu německého katolického kléru z českých zemí, Securitas imperii 32/1, 2018, s. $98-129$. 
mohla vést mezi odsunutými a těmi, kteří nadále mohli (či někdy museli) v Československu zůstat. Nakolik však sám Rabas odsun hodnotil, jak ho vnímal a co přesně v letech 1945 až 1946 prožíval, bohužel nevíme, žádné $\mathrm{k}$ tomu relevantní dokumenty či výpovědi jsme neměli k dispozici. Tyto otázky jsou důležité i z toho pohledu, že zmíněná krize $\mathrm{F}$. Rabasovi zároveň umožnila nalézt další životní uplatnění. Jeho upř́mná snaha pomoci biskupu Trochtovi s budováním „nové“ litoměřické diecéze zejména na poli formace kněžského dorostu, již snad lze přirovnat $\mathrm{k}$ jeho předchozímu působení v serafínských školách, kdy také spoluutvářel nastupující generaci českých kapucínů a v níž do jisté míry (vědomě či nevědomě?) navazoval na předchozí aktivity svého bratra Josefa, mohla být za jiných okolností korunována úspěchem a mohla by být vyvrcholením jeho života - stala se však tragédií.

Tento zásadní životní zvrat způsobila poslední zásadní krize katolické církve, jíž F. Rabas čelil, a sice její perzekuce ze strany komunistického režimu po roce 1948. Jeho výše zmíněné aktivity a nesmlouvavý postoj k možnosti zásadních ústupků ve prospěch státních orgánů způsobily, že spolu se svým biskupem a dalšími spolupracovníky byl odsouzen $\mathrm{k}$ mnohaletému žaláři. A to místo možného zhodnocení dosavadních znalostí a zkušeností ve formování budoucích duchovních či budování další „akademické“ kariéry, k čemuž by mohlo dojít, kdyby třeba změnil své zásady a přesvědčení nebo byl rovněž po válce odsunut. V tomto kontextu však možná až paradoxně vyznívá, že ačkoliv se zřejmě cítil být spíše Čechem, kvưli čemuž zakusil nejhorší léta svého života, místo svého posledního odpočinku nalezl u svého bratra v Německu.

\section{Grantová podpora}

Tato studie vznikla v rámci programu Univerzity Karlovy Progres Q23: Dějiny univerzitní vědy a vzdělanosti 


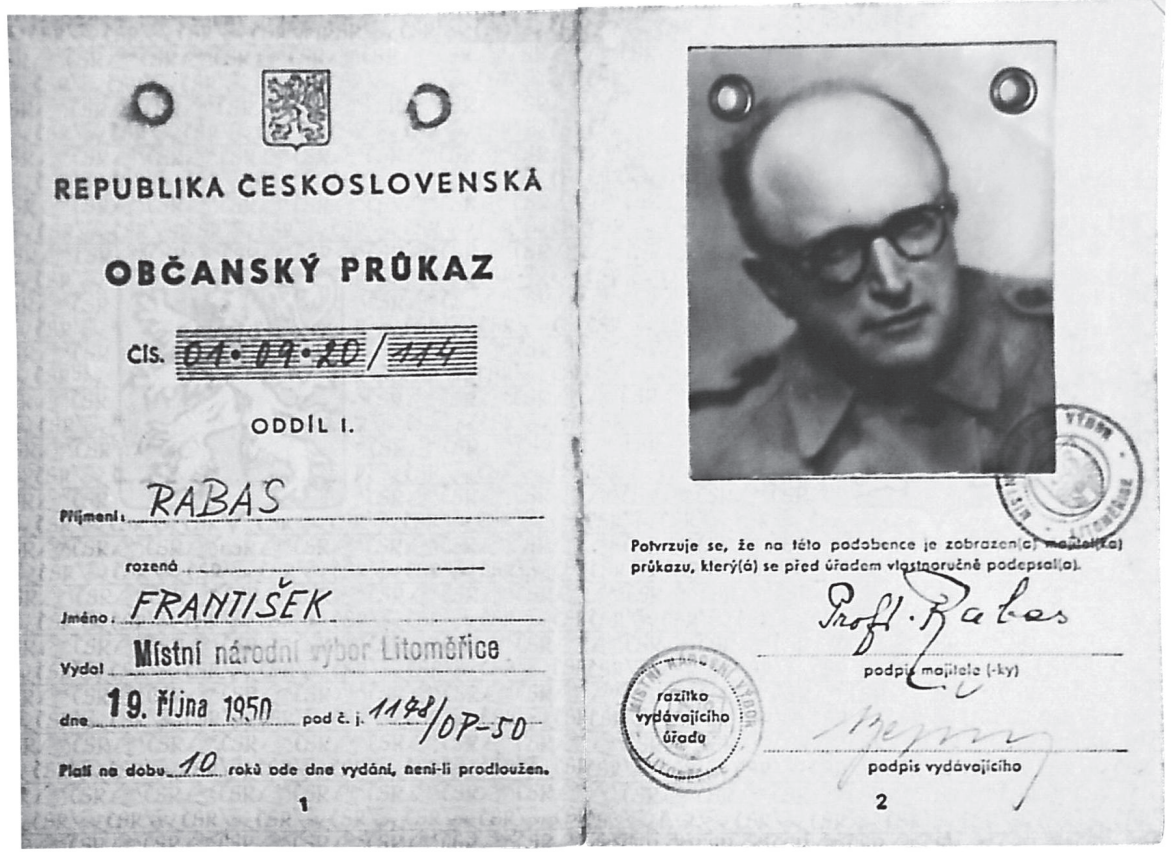

Občanský průkaz Františka Rabase vystavený MNV v Litoměřicích 19. října 1950

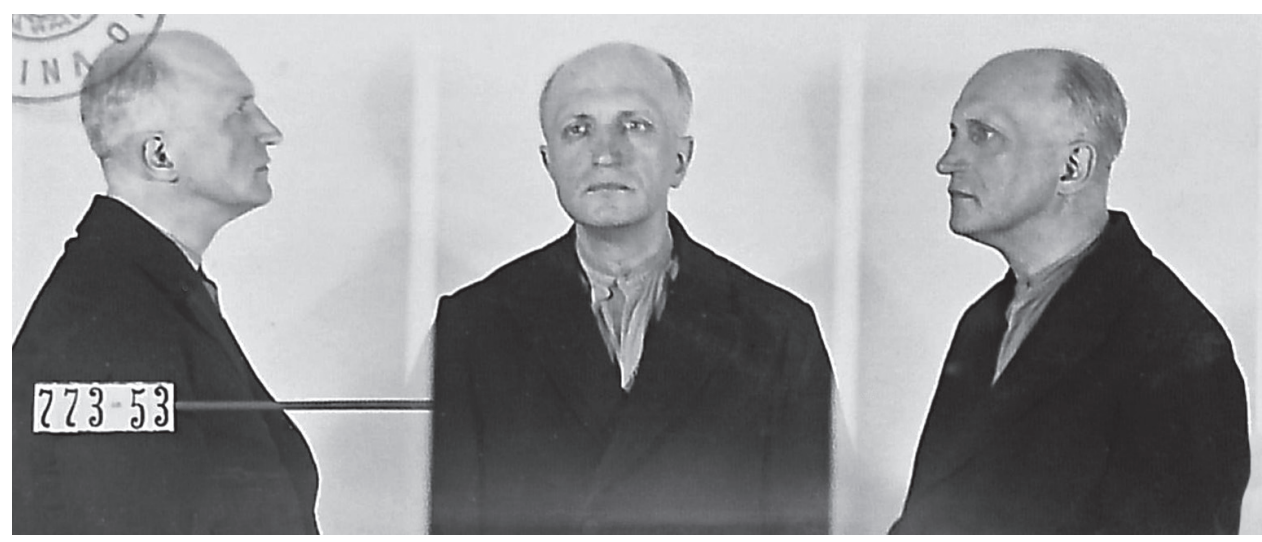

František Rabas na fotografii pořízené v době jeho vyšetřování

(Obě fotografie Archiv bezpečnostních složek, sbírka Správa vyšetřování StB - vyšetřovací spisy (V), arch. č. V-2309 MV.) 


\title{
FRANTIŠEK VAVŘINEC RABAS OFMCAP (1901-1969) ALS PÄDAGOGE UND ENGER MITARBEITER DES LEITMERITZER BISCHOFS ŠTĚPÁN TROCHTA
}

\author{
ZUSAMMENFASSUNG
}

František Rabas wurde am 20. September 1901 in Žatec (Saaz) in einer deutsch-tschechischen Familie geboren. Mit 16 Jahren trat er in den Kapuzinerorden ein, was sein Leben prinzipiell veränderte und ihm nicht nur wegen seines Ordensnamens Vavřinec eine neue Richtung wies. Die erforderlichen Studien absolvierte er in Olomouc (Olmütz), darüber hinaus auch im schweizerischen Freiburg und in Prag. Hier verbrachte er im Hradschiner Konvent das Ende der 1920er und die meiste Zeit der 1930er Jahre, wobei er Erzieher und Pädagoge in der sogenannten seraphischen Schule war, die unter anderem zwecks Zuwachs ihrer Ordensmitglieder gerade von den Kapuzinern betrieben wurde. Außerdem war er auch Bibliothekar der Kapuziner Provinzbibliothek auf dem Prager Hradschin, wodurch er Zugang zu den dort aufbewahrten Provinzchroniken hatte, was er in zahlreichen Texten zur Geschichte des Kapuzinerordens in den böhmischen Ländern in der Frühen Neuzeit verwertete, die von Forschern bis heute genutzt werden. Während des Zweiten Weltkriegs kehrte er nach Olomouc zurück, wo er im Studium Philosophicum des Ordens und gleichzeitig in der theologischen Lehranstalt der Erzdiözese lehrte. Im Jahre 1945 entschloss er sich aus eigenem Antrieb, aus dem Kapuzinerorden auszutreten. Von da an - bzw. ab Ausgabe des Exklaustrationsdekrets Anfang 1946 - benutzt er wieder den Namen František. Nach kurzem Wirken in der Seelsorge der Olmützer Erzdiözese gelangte er im Sommer 1946 dank persönlicher Verbindungen nach Litoměřice (Leitmeritz), wo er als Lehrbeauftragter an der dortigen theologischen Lehranstalt der Diözese tätig zu werden begann. Später wurde er Rektor des dortigen Priesterseminars, und dank dem Vertrauen des neuen residierenden Bischofs Štěpán Trochta wurde er im Rahmen des dortigen Konsistoriums und Diözesangerichts auf bedeutende Weise in die Diözesanleitung eingebunden. Im Jahre 1949 baute Bischof Trochta aus Furcht vor Repressalien des neuen Regimes eine geheime Verwaltungsstruktur der Leitmeritzer Diözese auf, in der Rabas geheimer erster Stellvertreter des Generalvikars und geheimer Regionalvikar für die Region Litoměřice wurde. Nach Schließung des Leitmeritzer Seminars im Sommer 1950 musste er (zweifellos unter dem Druck der staatlichen Behörden) in die Seelsorge gehen, und zwar zunächst nach Litvínov und anschließend nach Cvikov in der Region Česká Lípa. Hier wurde er im Januar 1953 verhaftet und wegen seiner Einbeziehung in die geheimen Verwaltungsstrukturen der Diözese und wegen weiterer „,antistaatlicher“ Betätigung gemeinsam mit seinem Bischof und anderen Mitarbeitern zu langjährigem Freiheitsentzug verurteilt. Aus dem Gefängnis wurde er 1964 entlassen und war gezwungen, im Diözesanheim für alte Priester in Senohraby bei Benešov zu wohnen. Im Herbst 1969 erhielt er die Erlaubnis für einen Besuch bei seinem Bruder in München, wo er am 30. Oktober 1969 auch verstarb. Angesichts der durch den Austritt aus dem Kapuzinerorden erfolgten Namensänderung wurde er in der Historiografie bislang oft als zwei Personen wahrgenommen, also entweder als Kapuziner und Historiograf oder als Rektor des Leitmeritzer Seminars und politischer Gefangener. Der vorliegende Aufsatz hat beide getrennte Identitäten miteinander verbunden und liefert zahlreiche wertvolle Details und Zusammenhänge zu seinem Leben.

(C) Deutsche Übersetzung Wolf B. Oerter

\author{
Mgr. Martin Barus \\ Archiv Biskupství litoměřckého \\ barus@dltm.cz
}

PhDr. Marek Brčák, Ph.D.

Ústav dějin a archiv Univerzity Karlovy

marek.brcak@ruk.cuni.cz 